\title{
Observation of atmospheric peroxides during Wangdu Campaign 2014 at a rural site in the North China Plain
}

\author{
Yin Wang, Zhongming Chen, Qinqin Wu, Hao Liang, Liubin Huang, Huan Li, Keding Lu, Yusheng Wu, \\ Huabin Dong, Limin Zeng, and Yuanhang Zhang
}

State Key Laboratory of Environmental Simulation and Pollution Control, College of Environmental Sciences and Engineering, Peking University, Beijing 100871, China

Correspondence to: Zhongming Chen (zmchen@pku.edu.cn)

Received: 4 April 2016 - Published in Atmos. Chem. Phys. Discuss.: 15 April 2016

Revised: 26 July 2016 - Accepted: 18 August 2016 - Published: 6 September 2016

\begin{abstract}
Measurements of atmospheric peroxides were made during Wangdu Campaign 2014 at Wangdu, a rural site in the North China Plain (NCP) in summer 2014. The predominant peroxides were detected to be hydrogen peroxide $\left(\mathrm{H}_{2} \mathrm{O}_{2}\right)$, methyl hydroperoxide (MHP) and peroxyacetic acid (PAA). The observed $\mathrm{H}_{2} \mathrm{O}_{2}$ reached up to 11.3 ppbv, which was the highest value compared with previous observations in China at summer time. A box model simulation based on the Master Chemical Mechanism and constrained by the simultaneous observations of physical parameters and chemical species was performed to explore the chemical budget of atmospheric peroxides. Photochemical oxidation of alkenes was found to be the major secondary formation pathway of atmospheric peroxides, while contributions from alkanes and aromatics were of minor importance. The comparison of modeled and measured peroxide concentrations revealed an underestimation during biomass burning events and an overestimation on haze days, which were ascribed to the direct production of peroxides from biomass burning and the heterogeneous uptake of peroxides by aerosols, respectively. The strengths of the primary emissions from biomass burning were on the same order of the known secondary production rates of atmospheric peroxides during the biomass burning events. The heterogeneous process on aerosol particles was suggested to be the predominant sink for atmospheric peroxides. The atmospheric lifetime of peroxides on haze days in summer in the NCP was about $2-3 \mathrm{~h}$, which is in good agreement with the laboratory studies. Further comprehensive investigations are necessary to better understand the impact of biomass burning and heterogeneous uptake on the concentration of peroxides in the atmosphere.
\end{abstract}

\section{Introduction}

Atmospheric peroxides, including hydrogen peroxide $\left(\mathrm{H}_{2} \mathrm{O}_{2}\right)$ and organic peroxides ( $\left.\mathrm{ROOH}\right)$, are vital oxidants present in the gaseous, aqueous and particulate phase in the atmospheric chemical processes. They serve as temporary reservoirs for $\mathrm{HO}_{x}$ radicals, contributing to the atmospheric oxidation capacity (Reeves and Penkett, 2003). Peroxides also participate in the conversion of $S(I V)$ to $S(V I)$ in the aqueous phase, leading to the acid precipitation and the formation of secondary sulfate $\left(\mathrm{SO}_{4}^{2-}\right)$ aerosols in the troposphere (Calvert et al., 1985; Stein and Saylor, 2012). Furthermore, atmospheric peroxides are considered as the key components of secondary organic aerosol (SOA), which play a significant role in the formation and duration of haze pollution (Kroll and Seinfeld, 2008; Ziemann and Atkinson, 2012; Li et al., 2016). In addition, it has been suggested that atmospheric peroxides are toxic to ecosystem and may be the critical pollutants of forest decline (Hellpointner and Gäb, 1989; Chen et al., 2010). More importantly, peroxides in the particle phase have been found to act as reactive oxygen species (ROS) and result in adverse influence on human health (Ayres et al., 2008).

The concentrations of atmospheric peroxides are determined by their production and destruction. The known formation pathways of peroxides in the atmosphere are primary emissions, for instance, biomass burning (Lee et al., 1997, 1998; Yokelson et al., 2009), and secondary sources such as peroxy radical self/cross reactions and the ozonolysis of unsaturated volatile organic compounds (VOCs), as shown in Reactions (R1), (R2) and (R3), (R4), respectively (Hewitt and Kok, 1991; Neeb et al., 1997; Sauer et al., 2001; 
Chao et al., 2015; Winiberg et al., 2016). Additionally, atmospheric aqueous reactions in the bulk solution or on the surface of wet particles coupled with subsequent release to the gas phase could also generate peroxides in the troposphere (Wang et al., 2012; Liang et al., 2013a; R. Zhao et al., 2013). The typical removal pathways of peroxides in the atmosphere are photolysis (Reactions R5, R6), reaction with $\mathrm{OH}$ radicals (Reactions R7, R8) and physical deposition (Atkinson et al., 2006; Sander et al., 2011; Nguyen et al., 2015). Heterogeneous uptake by atmospheric aerosols is recognized as another significant sink for peroxides in the troposphere, especially in dusty and polluted urban areas (Y. Zhao et al., 2013; Wu et al., 2015).

$$
\begin{aligned}
& \mathrm{HO}_{2}+\mathrm{HO}_{2} \rightarrow \mathrm{H}_{2} \mathrm{O}_{2}+\mathrm{O}_{2} \\
& \mathrm{RO}_{2}+\mathrm{HO}_{2} \rightarrow \mathrm{ROOH}+\mathrm{O}_{2} \\
& \mathrm{RCH}=\mathrm{CH}_{2}+\mathrm{O}_{3} \rightarrow \mathrm{RCHOO}+\mathrm{HCHO} \\
& \mathrm{RCHOO}+\mathrm{H}_{2} \mathrm{O} \rightarrow \mathrm{RCH}(\mathrm{OH}) \mathrm{OH} \\
& \mathrm{H}_{2} \mathrm{O}_{2}+h v \rightarrow \mathrm{OH}+\mathrm{OH} \\
& \mathrm{ROOH}+h v \rightarrow \mathrm{RO}+\mathrm{OH} \\
& \mathrm{H}_{2} \mathrm{O}_{2}+\mathrm{OH} \rightarrow \mathrm{HO}_{2}+\mathrm{H}_{2} \mathrm{O} \\
& \mathrm{ROOH}+\mathrm{OH} \rightarrow \mathrm{RO}_{2}+\mathrm{H}_{2} \mathrm{O}
\end{aligned}
$$

In the past years, a number of field observations, laboratory studies and modeling research have been carried out to investigate the abundance and behavior of peroxides in the atmosphere (Chen et al., 2008; Mao et al., 2010; Huang et al., 2013; Liang et al., 2013a; Sarwar et al., 2013; Epstein et al., 2014; Fischer et al., 2015; Khan et al., 2015). Hydrogen peroxide $\left(\mathrm{H}_{2} \mathrm{O}_{2}\right)$, hydroxymethyl hydroperoxide (HMHP, $\mathrm{HOCH}_{2} \mathrm{OOH}$ ), methyl hydroperoxide (MHP, $\mathrm{CH}_{3} \mathrm{OOH}$ ) and peroxyacetic acid $\left(\mathrm{PAA}, \mathrm{CH}_{3} \mathrm{C}(\mathrm{O}) \mathrm{OOH}\right)$ are generally determined to be the principal peroxide compounds in the troposphere with their concentrations ranging from pptv (parts per trillion by volume) to ppbv (parts per billion by volume) (Lee et al., 2000; He et al., 2010; Zhang et al., 2010, 2012). However, to date, there have been limited studies concerned with atmospheric peroxides in the regions primarily affected by anthropogenic sources such as the North China Plain (NCP), which is a typical region with frequent biomass burning and suffering from serious haze pollution in China (Tao et al., 2012; Huang et al., 2014). Few numerical simulations focused on atmospheric peroxides in the NCP are conducted to examine whether the models can reproduce the observations of peroxides (Liang et al., 2013a). The impact of biomass burning and high aerosol loading on the atmospheric chemistry of peroxides over such a polluted region is poorly understood. Therefore, this work was carried out in order to make an endeavor to fill in these research gaps.

In this study, we present a novel data set of atmospheric speciated peroxides and explore their atmospheric chemistry at a rural site, Wangdu, which represents regional air pollution conditions of the NCP during Wangdu Campaign 2014. Given the diversity of emission sources and chemical trans- formation of atmospheric peroxides over this region, it is challenging to analyze the phenomena and understand the primary emission and secondary formation of peroxides in the atmosphere during this field observation. However, with the continuous measurements of atmospheric peroxides, physical parameters and other chemical species performed simultaneously, a quantitative assessment of the budget of atmospheric peroxides can be carried out employing the zerodimensional model based on Master Chemical Mechanism (MCM) and constrained by observed meteorological parameters and trace gases, which provides a good opportunity to comprehensively facilitate our knowledge of the chemistry of atmospheric peroxides in the NCP. As far as we know, this is the first study to test whether current atmospheric peroxides related chemistry could explain the field observation in the rural area of the NCP. Through the comparison between measurement and simulation, our aim is to investigate the role of biomass burning and heterogeneous uptake on aerosols in the concentration of atmospheric peroxides, which helps to develop a more robust mechanism in the model.

\section{Experiments}

\subsection{Measurement site}

Measurements of atmospheric peroxides were performed at Wangdu site $\left(38.66^{\circ} \mathrm{N}, 115.20^{\circ} \mathrm{E}\right)$ in Baoding city, Hebei Province, a rural supersite for the Wangdu Campaign 2014 situated in the northwest of the NCP, about $200 \mathrm{~km}$ southwest of the mega-city Beijing. The surrounding regions of Wangdu site are mainly agricultural fields. There are almost no industries near this site. During the summer season, the air pollution is caused by the primary emission from biomass burning and secondary formation including photochemical and heterogeneous processes. The instruments were placed in a container with the sampling inlet approximately $5 \mathrm{~m}$ above the ground. The continuous observation of atmospheric peroxides was conducted from 4 June to 7 July 2014.

\subsection{Measurement methods}

\subsubsection{Measurement method for atmospheric peroxides}

Atmospheric peroxide concentrations were investigated by an automated on-site high performance liquid chromatography (HPLC) with post-column enzyme derivatization and detected by fluorescence spectroscopy. Air samples were pumped through a glass scrubbing coil maintained at a controlled temperature of about $4{ }^{\circ} \mathrm{C}$ to collect the peroxides in the atmosphere. The flow rate of air samples was set to be 2.7 standard $\mathrm{L} \mathrm{min}^{-1}$. The stripping solution, $5 \times 10^{-3} \mathrm{M} \mathrm{H}_{3} \mathrm{PO}_{4}$ in water was delivered into the scrubbing coil collector. The flow rate of stripping solution was set to be $0.2 \mathrm{~mL} \mathrm{~min}^{-1}$. Once the air samples mixed with the stripping solution in the collector, the mixture was car- 
ried by the mobile phase containing $5 \times 10^{-3} \mathrm{M} \mathrm{H}_{3} \mathrm{PO}_{4}$ at $0.5 \mathrm{~mL} \mathrm{~min}^{-1}$ and injected into HPLC. The peroxide components were separated after the mixture passed through HPLC column. With the catalysis of Hemin at $\sim 40^{\circ} \mathrm{C}$, the derivatization reaction between peroxide components and parahydroxyphenylacetic acid (PHPAA) produced the fluorescent matter that can be quantified by a fluorescence detector. In this work, atmospheric peroxides were measured every $20 \mathrm{~min}$. The collection efficiencies for hydrogen peroxide and organic peroxides were determined to be 100 and $85 \%$, respectively. The detection limit of peroxides in the gas phase was about 10 pptv.

The interference of $\mathrm{SO}_{2}$ on the sampling was estimated using the theoretical thermodynamic and kinetic analysis presented in Hua et al. (2008). Considering the rate constant for reaction between peroxides and $\mathrm{S}(\mathrm{IV})$ reported by Ervens et al. (2003) and the mean level of $\mathrm{SO}_{2}$ was $7.0 \pm 7.0$ ppbv during the campaign, the negative artifact caused by $\mathrm{SO}_{2}$ interference for peroxides was calculated to be less than $15 \%$. The influence of ambient relative humidity (RH) on the measurement of atmospheric peroxides was calculated following the method introduced by Liang et al. (2013b). The change of the concentration of atmospheric peroxides after this calibration was less than $10 \%$. Here, we did not correct the observational data for any artifacts due to the uncertainties from the theoretical estimation of peroxides loss that possibly result in new errors. The uncertainty of our observational data is estimated to be $\sim 15 \%$. Further details about our measurement method for atmospheric peroxides can be obtained from Hua et al. (2008).

\subsubsection{Measurement methods for other pollutants and parameters}

During Wangdu Campaign 2014, $\mathrm{SO}_{2}, \mathrm{CO}, \mathrm{NO} / \mathrm{NO}_{2}$ and $\mathrm{O}_{3}$ were measured concurrently at this supersite using a suite of commercial instruments (Thermo 43i, 42i, 48i and 49i). HONO was measured every 2 min with a LOng Path Absorption Photometer (LOPAP) (Liu et al., 2016). $\mathrm{C}_{2}-\mathrm{C}_{10}$ nonmethane hydrocarbons (NMHCs) were analyzed with a time resolution of $60 \mathrm{~min}$ by a custom-built online VOC analyzer using automated gas chromatography (GC) coupled with flame ionization detector (FID) or mass spectrometry (MS) technique (Wang et al., 2014). $\mathrm{OH}$ and $\mathrm{HO}_{2}$ radicals were measured by laser-induced fluorescence (LIF) spectroscopy (Tan et al., 2016). Size distributions of aerosols $\left(\mathrm{PM}_{10}\right)$ were determined every 10 min with a Twin Differential Mobility Particle Sizer (TDMPS) and an Aerodynamic Particle Sizer (APS) to calculate dry particle surface area concentrations $\left(S_{\mathrm{a}}\right)$. Hygroscopic growth factor, $f(\mathrm{RH})$, which is defined as the ratio of scattering coefficient for ambient aerosol to scattering coefficient for dry aerosol, was derived from the integrating nephelometer (Liu, 2015). Measurements of the mass concentration of $\mathrm{PM}_{2.5}$ were obtained by TEOM 1400A analyzer. Water-soluble ions (i.e., $\mathrm{NH}_{4}^{+}, \mathrm{K}^{+}, \mathrm{Cl}^{-}, \mathrm{SO}_{4}^{2-}$ and
$\mathrm{NO}_{3}^{-}$) in $\mathrm{PM}_{2.5}$ was measured every 30 min with a Gas and Aerosol Collector (GAC) (Ye, 2015). Photolysis frequencies were derived from a spectro-radiometer (Bohn et al., 2008). Meteorological parameters including ambient temperature, relative humidity $(\mathrm{RH})$, pressure, wind speed, wind direction and rainfall were monitored continuously by a weather station. The uncertainties $(1 \sigma)$ in these measurements are estimated as $5 \%$ for $\mathrm{NO}, \mathrm{O}_{3}$, and $\mathrm{CO}, 10 \%$ for $\mathrm{H}_{2} \mathrm{O}, \mathrm{NO}_{2}$, HONO, NMHCs, and solar radiation, and $20 \%$ for $S_{\mathrm{a}}$.

\subsection{Model description}

A zero-dimensional box model using a near-explicit mechanism, MCM Version 3.3.1 (http://mcm.leeds.ac.uk/MCM/) (Jenkin et al., 1997, 2003; Saunders et al., 2003; Jenkin et al., 2015) was employed to examine the influence of biomass burning and heterogeneous uptake on the budget of atmospheric peroxides. MCMv3.3.1 describes the degradation of 143 VOCs, leading to about 5800 species and 17000 reactions. In the current study, we extracted a subset of MCMv3.3.1 containing the reactions of atmospheric oxidants with measured VOCs and subsequent chemical products. Measurements of $\mathrm{NO} / \mathrm{NO}_{2}, \mathrm{CO}, \mathrm{O}_{3}, \mathrm{HONO}, \mathrm{NMHCs}$, temperature, pressure and $\mathrm{H}_{2} \mathrm{O}$ were used as inputs to constrain the model calculations. The model ran with a 5-min time step and a spin-up time of 2 days to reach a steady state.

Photolysis frequencies were calculated by the Tropospheric Ultraviolet and Visible (TUV, version 5.2) model (Madronich, 2002), and further rescaled with the measured $j\left(\mathrm{NO}_{2}\right)$. Dry deposition velocities of trace gases in our box model were parameterized as $V_{\mathrm{d}} / h$ (Seinfeld and Pandis, 2006), where $V_{\mathrm{d}}$ is the dry deposition rate of species and $h$ is the height of planetary boundary layer (PBL). Dry deposition rates of $\mathrm{HNO}_{3}$, PANs, organic nitrates, $\mathrm{H}_{2} \mathrm{O}_{2}$, organic peroxides and aldehydes incorporated in the model were set as $2.0 \times 10^{-5}, 5.0 \times 10^{-6}, 1.0 \times 10^{-5}, 1.0 \times 10^{-5}, 5.0 \times 10^{-6}$ and $1.0 \times 10^{-5} \mathrm{~s}^{-1}$, respectively at the PBL height of $1 \mathrm{~km}$ (Zhang et al., 2003; Emmerson et al., 2007; Lu et al., 2012; Guo et al., 2014; X. Li et al., 2014; Liu et al., 2015; Nguyen et al., 2015). The PBL height over Wangdu during this campaign was derived from the hybrid single-particle lagrangian integrated trajectory (HYSPLIT) model (Draxler and Rolph, 2012), which varied between about $300 \mathrm{~m}$ at midnight and over $3000 \mathrm{~m}$ at noon.

The uncertainty of our model calculation derives from the uncertainty of observational data, PBL height and reaction rate coefficients in chemical mechanism. The total uncertainty in the model is estimated from the errors of all input parameters using error propagation, which is similar to the method that can be found in Hofzumahaus et al. (2009). On average, the modeled concentration of atmospheric peroxides has an uncertainty of approx. $60 \%$.

In the present study, to explore the impact of the heterogeneous process on the concentration of atmospheric peroxides, our box model is extended with the aerosol uptake of 


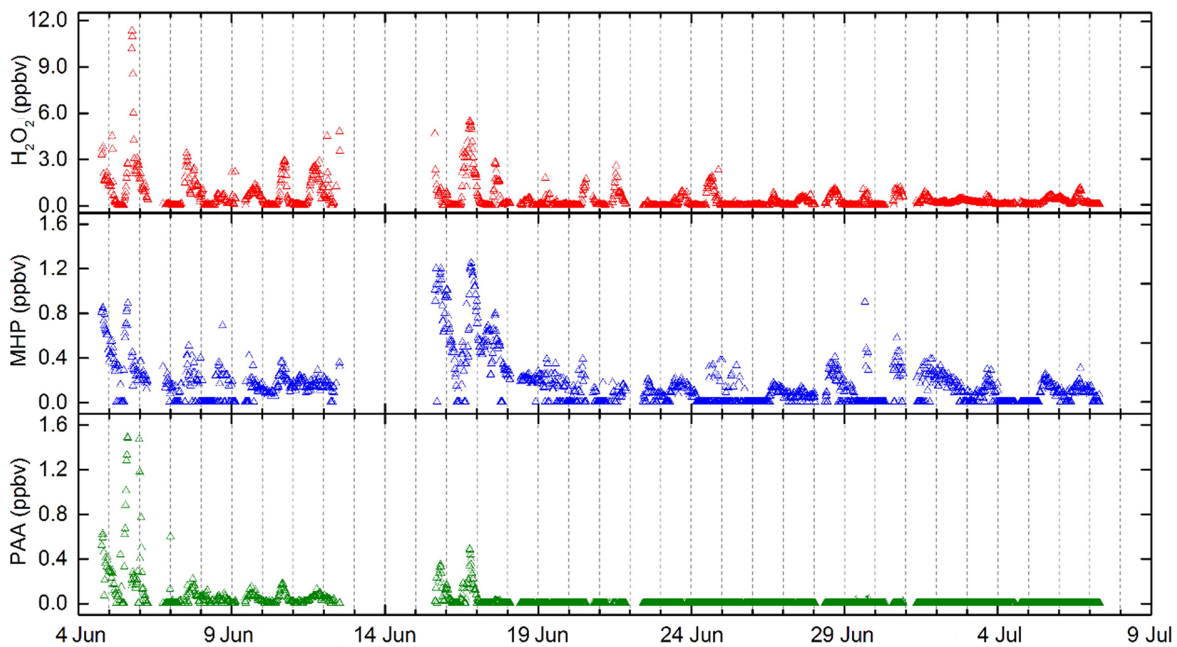

Figure 1. Temporal profile for atmospheric peroxides over the entire Wangdu Campaign 2014.

peroxides. The pseudo-first-order rate constant for the heterogeneous uptake of peroxides on ambient aerosols is parameterized as follows:

$k=\frac{1}{4} \gamma \times v \times S_{\mathrm{aw}}$,

(Jacob, 2000), where $\gamma$ is the uptake coefficient, $v$ is the mean molecular velocity, $S_{\text {aw }}$ is the aerosol surface concentration corrected by the measured hygroscopic factor, $f(\mathrm{RH})$ that could be expressed as $S_{\mathrm{aw}}=S_{\mathrm{a}} \times f(\mathrm{RH})$.

\section{Results and discussion}

\subsection{General observations}

The concentrations of peroxides in the atmosphere were measured continuously from 4 June to 7 July 2014. The predominant peroxides over Wangdu included $\mathrm{H}_{2} \mathrm{O}_{2}$, MHP and PAA. Time series for atmospheric peroxides during Wangdu Campaign 2014 are illustrated in Fig. 1. The statistical data about the observed concentration of atmospheric peroxides are summarized and given in Table 1. It should be noted that values below the detection limit (D.L.) of our instrument were replaced by half of the D.L. in Fig. 1, Fig. 2 and statistical calculations. In this study, $\mathrm{H}_{2} \mathrm{O}_{2}$ accounted for $\sim 70 \%$ of total detected peroxides $\left(\mathrm{H}_{2} \mathrm{O}_{2}+\mathrm{MHP}+\mathrm{PAA}\right)$ similar to those determined at other rural sites in China. However, in our previous work, $\mathrm{H}_{2} \mathrm{O}_{2}$ contributed not more than $30 \%$ of total peroxides in the atmosphere over urban Beijing in the summer time of 2010 and 2011 (Liang et al., 2013b). This might be caused by the difference on the production and destruction of atmospheric peroxides between two sites. MHP and PAA were determined to be about 20 and $5 \%$ of total peroxides over Wangdu, respectively, which is similar to the
Table 1. Summary of the concentrations of atmospheric peroxides during Wangdu Campaign 2014.

\begin{tabular}{|c|c|c|c|c|}
\hline & & $\begin{array}{l}\mathrm{H}_{2} \mathrm{O}_{2} \\
(\mathrm{ppbv})\end{array}$ & $\begin{array}{r}\text { MHP } \\
(\mathrm{ppbv})\end{array}$ & $\begin{array}{r}\text { PAA } \\
(\mathrm{ppbv})\end{array}$ \\
\hline & D.L. $^{\mathrm{a}}$ & 0.01 & 0.01 & 0.01 \\
\hline \multirow[t]{5}{*}{$24 \mathrm{~h}$} & $N^{\mathrm{b}}$ & 1797 & 1797 & 1797 \\
\hline & Mean & 0.51 & 0.16 & 0.03 \\
\hline & $\mathrm{SD}^{\mathrm{c}}$ & 0.90 & 0.21 & 0.11 \\
\hline & Median & 0.19 & 0.11 & 0.01 \\
\hline & Maximum & 11.3 & 1.25 & 1.49 \\
\hline \multirow{5}{*}{$\begin{array}{l}\text { Daytime } \\
\left(06: 00-18: 00 \mathrm{LT}^{\mathrm{d}}\right)\end{array}$} & $N^{\mathrm{b}}$ & 829 & 829 & 829 \\
\hline & Mean & 0.55 & 0.16 & 0.03 \\
\hline & $\mathrm{SD}^{\mathrm{c}}$ & 0.83 & 0.18 & 0.12 \\
\hline & Median & 0.24 & 0.12 & 0.01 \\
\hline & Maximum & 10.2 & 1.20 & 1.49 \\
\hline \multirow{5}{*}{$\begin{array}{l}\text { Nighttime } \\
\left(18: 00-06: 00 \mathrm{LT}^{\mathrm{d}}\right)\end{array}$} & $N^{\mathrm{b}}$ & 968 & 968 & 968 \\
\hline & Mean & 0.48 & 0.17 & 0.04 \\
\hline & $\mathrm{SD}^{\mathrm{c}}$ & 0.96 & 0.23 & 0.11 \\
\hline & Median & 0.15 & 0.11 & 0.01 \\
\hline & Maximum & 11.3 & 1.25 & 1.47 \\
\hline
\end{tabular}

${ }^{\mathrm{a}}$ D.L.: detection limit. ${ }^{\mathrm{b}} \mathrm{N}$ : number of samples. ${ }^{\mathrm{c}}$ SD: standard deviation.

d LT: local time.

results of other rural sites in China from our previous investigations (Zhang et al., 2010, 2012).

In the present work, on the basis of the latest national Ambient Air Quality Standards of China (GB3095-2012), the haze day is defined as a day with daily-averaged $\mathrm{PM}_{2.5}$ concentration over $75 \mathrm{\mu g} \mathrm{m}^{-3}$. The haze pollution episode is defined as the event that a set of continuous days with dailyaveraged $\mathrm{PM}_{2.5}$ concentration exceeding $75 \mu \mathrm{g} \mathrm{m}{ }^{-3}$, which has been used to distinguish non-haze and haze episode in 


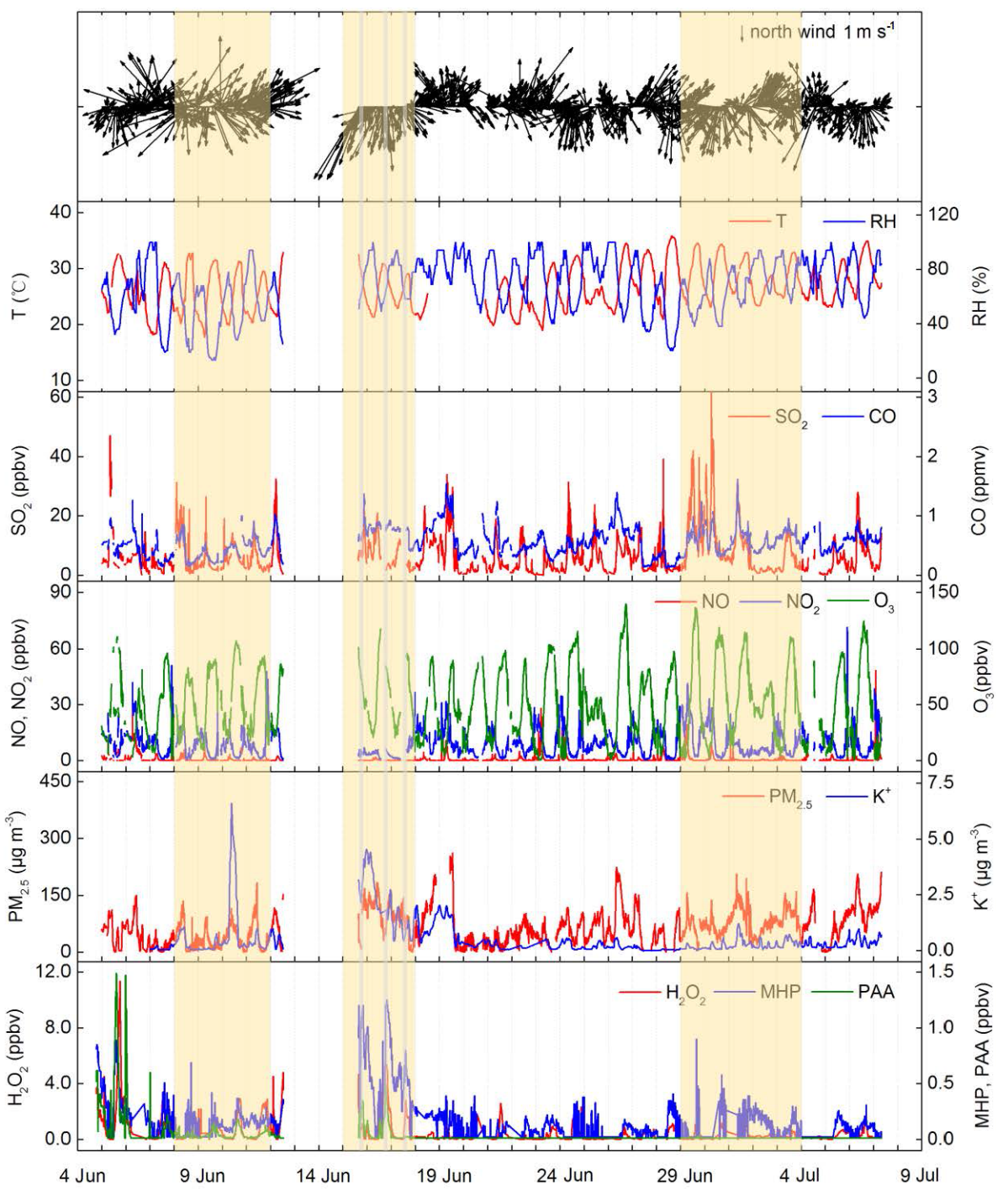

Figure 2. Time series of meteorological parameters, chemical species and atmospheric peroxides. The orange shaded area represents the Phase I (8-11 June), Phase II (15-17 June) and Phase III (29 June-3 July). The grey shaded area indicates three biomass burning events.

the literature (Che et al., 2014; Zhang et al., 2016; Zheng et al., 2015, 2016). During this campaign, there were four haze pollution episodes at Wangdu site as follows: Episode 1 (4-6 June), Episode 2 (12-17 June), Episode 3 (29 June3 July) and Episode 4 (5-7 July) with elevated average $\mathrm{PM}_{2.5}$ concentrations (75, 92, 79 and $99 \mu \mathrm{g} \mathrm{m}^{-3}$, respectively). In Episode $1, \mathrm{H}_{2} \mathrm{O}_{2}$, MHP and PAA were observed up to 11.3, 0.9 and $1.5 \mathrm{ppbv}$, respectively. The maximum $\mathrm{H}_{2} \mathrm{O}_{2}$ concentration on 5 June was the highest value so far among the previously reported observations in urban, suburban and rural areas in China at summer time. The possible reason for this peak concentration at Wangdu site could be the primary emission from biomass burning combined with the secondary formation by the intense photochemical process. Nevertheless, owing to the lack of supporting data for other pollutants and parameters, it is difficult to identify the rela- tive contributions of biomass burning versus photochemical formation to the burst of atmospheric peroxides on 5 June. In Episode 2, there was widespread and intensive biomass burning in the NCP as this observation period covered the local wheat harvest season. The evidence for biomass burning from the measurement of $\mathrm{K}^{+}$in $\mathrm{PM}_{2.5}$ was illustrated in Fig. 2. The sudden raise of atmospheric peroxides was observed and further discussed in Sect. 3.3. In Episode 3, there was a substantial decline of $\mathrm{H}_{2} \mathrm{O}_{2}$ level during this typical haze event compared with the foregoing two episodes, which can be ascribed to the heterogeneous uptake of peroxides on atmospheric aerosols on haze days over Wangdu (see Sect. 3.4). In Episode 4, Wangdu was significantly impacted by the regional transport (Ye, 2015). The concentrations of atmospheric peroxides remained relatively low compared with Episode 1 and Episode 2. In addition to the above- 


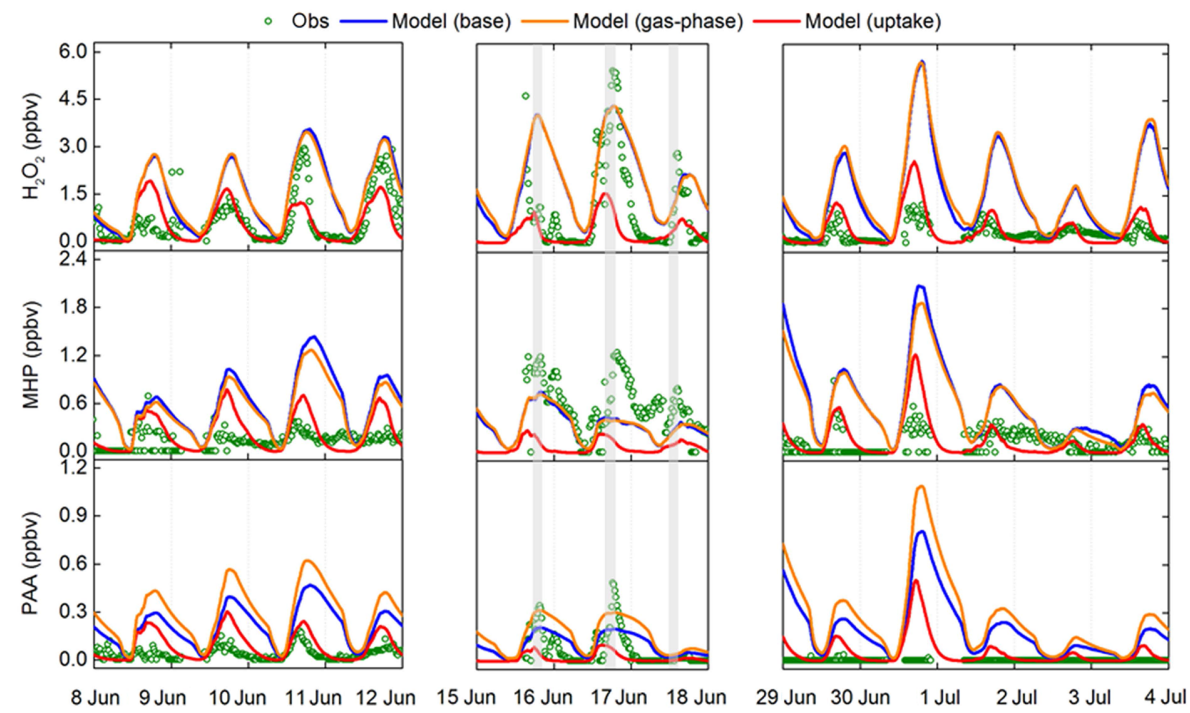

Figure 3. Observed and modeled concentrations of atmospheric peroxides for Phase I (8-11 June), Phase II (15-17 June) and Phase III (29 June-3 July). The green circles represent observed concentrations. The blue, orange and red lines indicate the modeled concentrations from three different scenarios: base case, new gas-phase reaction case and heterogeneous uptake case, respectively. The grey shaded area indicates three biomass burning events.

mentioned episodes, it was relatively clear between 8 and 11 June and 27 and 28 June, with mean $\mathrm{PM}_{2.5}$ concentrations under $40 \mu \mathrm{g} \mathrm{m}^{-3}$. The intermittent thunderstorm activities occurred from 19 to 25 June, which caused the electric power failure and several data gaps.

\subsection{Peroxide simulation}

In this study, we employed a box model based on the MCMv3.3.1 to simulate $\mathrm{H}_{2} \mathrm{O}_{2}$, MHP and PAA concentrations. Here, to explore the atmospheric chemistry of peroxides on non-haze, biomass burning and haze days, the observational data from 8 to 11 June (Phase I), from 15 to 17 June (Phase II) and from 29 June to 3 July (Phase III) in 2014 were selected as phase of interest and analyzed in detail using box model in the following sections. The temporal variations of meteorological parameters, chemical species and atmospheric peroxides for the whole campaign are displayed in Fig. 2. The observed and calculated levels of atmospheric peroxides for the three phases are illustrated in Fig. 3. During these case study phases, $75 \%$ of the wind speed data were $\leq 2.2 \mathrm{~m} \mathrm{~s}^{-1}$ and the mean value was $1.6 \mathrm{~m} \mathrm{~s}^{-1}$. It has been shown that the atmospheric lifetimes of peroxides are on the order of several hours as reported previously (He et al., 2010; Wu et al., 2015), implying that the effect of regional transport or dilution on the concentrations of atmospheric peroxides was of little significance over Wangdu. Hence, the regionalscale transport can be excluded in our box model and the budgets of peroxides are, to a large extent, dependent on local chemical processes during the observation.
In the Phase I, as shown in Fig. 4, the model base case prediction of $\mathrm{H}_{2} \mathrm{O}_{2}$ level had good performance in the daytime (06:00-18:00 local time), which was 1-2 times higher than the measurement results. This seems to be explained by the model-measurement uncertainty. Similarly, a previous observation carried out at a suburban site also showed reasonable model-measurement agreement in $\mathrm{H}_{2} \mathrm{O}_{2}$ level on sunny days (Guo et al., 2014). The excellent description yielded by the model base case indicated that the production and destruction of $\mathrm{H}_{2} \mathrm{O}_{2}$ in the atmosphere on non-haze days were calculated correctly based on the current understanding of atmospheric peroxide related chemistry. However, the simulation in the nighttime (18:00-06:00 LT) during the Phase I demonstrated an obvious overestimation compared to the observation by a factor of 4-6 and up to an order of magnitude. This large discrepancy between calculated and observed results is speculated to be resulted from the underestimation of sink terms as the key precursors governing the formation of atmospheric peroxides are constrained by the observation and the overestimation of source terms can be ruled out. It is consistent with the comparison of the simulated and observed $\mathrm{H}_{2} \mathrm{O}_{2}$ concentration over urban Beijing, in which the explanation for the overprediction of $\mathrm{H}_{2} \mathrm{O}_{2}$ level on haze days was thought to be the heterogeneous processes on liquid or solid particles that were missing from the current atmospheric chemistry model (Liang et al., 2013b). Considering the high aerosol loading in the NCP and the higher aerosol surface area concentration at nighttime $\left(1158 \mu \mathrm{m}^{2} \mathrm{~cm}^{-3}\right)$ than that at daytime $\left(773 \mu \mathrm{m}^{2} \mathrm{~cm}^{-3}\right)$ in the Phase I, we believe that the missing sink for atmospheric peroxides in the model base case is probably heterogeneous uptake of peroxides occurring on 

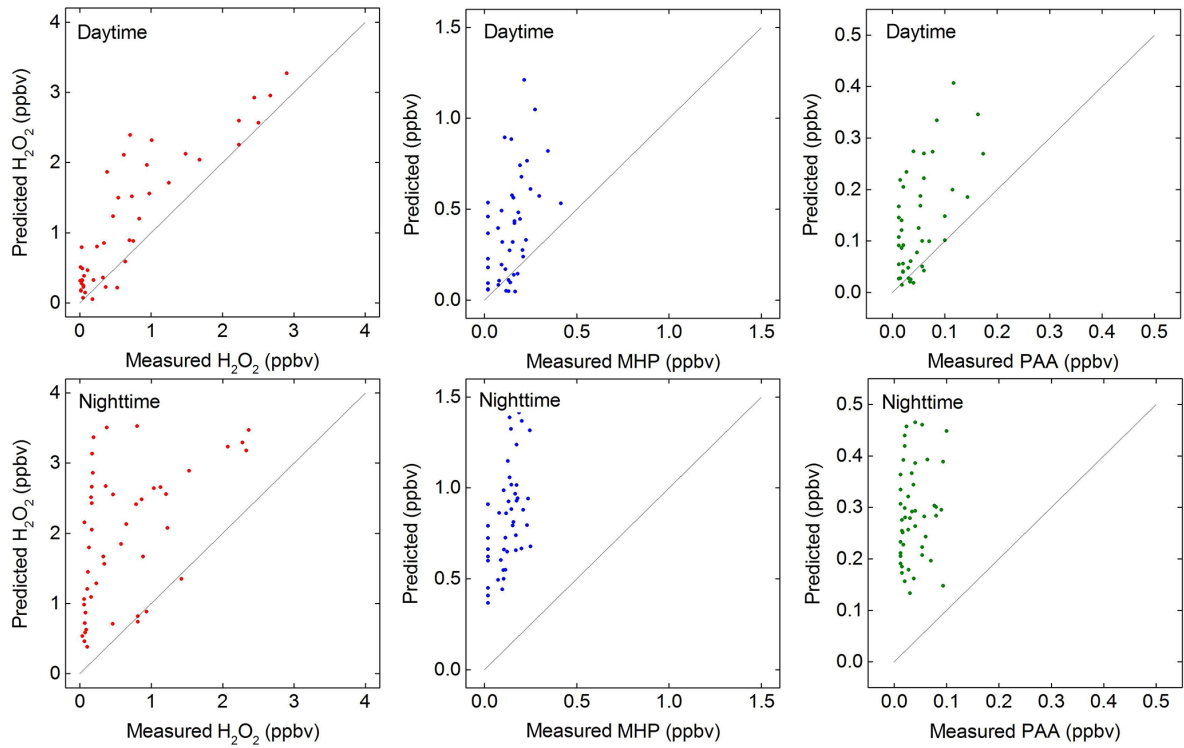

Figure 4. Comparisons between measured and predicted concentrations of atmospheric peroxides in the model base case for daytime and nighttime during the Phase I (8-11 June). The solid lines represent the $1: 1$ ratio of observed to modeled values.

aerosols. The strengths of the missing sinks for $\mathrm{H}_{2} \mathrm{O}_{2}$, MHP and PAA quantified by the difference between modeled and measured peroxide concentrations were about $0.24,0.09$ and $0.03 \mathrm{ppbv}^{-1}$ on average, respectively, which were on the same order of magnitude as the known loss rates of atmospheric peroxides during the Phase I.

In the Phase II, the comparison of the modeled and measured peroxide concentrations in Fig. 3 displays that the observed magnitude of atmospheric peroxides was unexpectedly large, indicating a missing source for peroxides. Such a strong imbalance was found only in the Phase II during the whole campaign. In the past, the higher-than-expected concentrations of atmospheric peroxides have also been reported by Lee et al. (1997), in which $\mathrm{H}_{2} \mathrm{O}_{2}$, MHP, PAA and other organic peroxides levels elevated near biomass burning plumes. Given the frequent fire emissions in the NCP during the Phase II that are quite similar to the conditions in Lee et al. (1997), it appears that the significant mismatch can be attributed to the direct production from biomass burning (see Sect. 3.3).

In the Phase III, the calculated values in the model base case showed a general tendency to strongly overestimate the observed values (Fig. 3). The modeled and measured shapes of the diurnal cycle of atmospheric peroxides were different. The haze arose on 29 June with the elevated $\mathrm{PM}_{2.5}$ concentration. The diffusion condition was poor as the $\mathrm{CO}$ concentration was enhanced. The precursors of atmospheric peroxides also accumulated on 29 and 30 June. The modeled peroxide concentrations were over 10 times higher than the measured peroxide concentrations. On 1 and 3 July, the dailyaveraged $\mathrm{PM}_{2.5}$ concentration was 1.6 times higher than those on 29 and 30 June. However, the photolysis frequen- cies and the PBL height on 1 and 3 July were about half of those on 29 and 30 June, which weakened the secondary formation of atmospheric peroxides and strengthened the loss of atmospheric peroxides via dry deposition. Although the haze on 1 and 3 July was more serious than that on 29 and 30 June, the ratios of modeled to measured peroxide concentrations on 1 and 3 July were much lower than those on 29 and 30 June. As there was a typical haze event during the Phase III, the model-measurement imbalance was probably due to the missing sink for atmospheric peroxides, which was the same deficiency in the model as that in the Phase I. It can be seen in Fig. 3 that with the inclusion of heterogeneous reactions on aerosol particles, the simulated concentrations of atmospheric peroxides were apparently improved and the modeled shape of the diurnal cycle of $\mathrm{H}_{2} \mathrm{O}_{2}$ was closer to the measured shape, which is further quantified in Sect. 3.4.

Before exploring the impact of biomass burning and heterogeneous uptake on the chemistry of atmospheric peroxides, we performed a model test by implementing the newly proposed chemical mechanisms for $\mathrm{CH}_{3} \mathrm{C}(\mathrm{O}) \mathrm{O}_{2}$ and $\mathrm{CH}_{3} \mathrm{O}_{2}$ related chemistry in MCMv3.3.1, as listed in Table 2. The rate constant and the branching ratios of the $\mathrm{CH}_{3} \mathrm{C}(\mathrm{O}) \mathrm{O}_{2}+\mathrm{HO}_{2}$ reaction that was the major pathway for the formation of PAA in this model scenario were modified according to the recent laboratory study conducted by Winiberg et al. (2016). Additionally, we also incorporated the reaction between $\mathrm{CH}_{3} \mathrm{O}_{2}$ radicals and $\mathrm{OH}$ radicals, which has as yet seldom been involved in atmospheric chemistry model. The reaction between $\mathrm{CH}_{3} \mathrm{O}_{2}$ radicals and $\mathrm{OH}$ radicals is recognized as an important sink for $\mathrm{CH}_{3} \mathrm{O}_{2}$ radicals with nonnegligible effect on subsequent formation of MHP under remote conditions (Bossolasco et al., 2014; Fittschen et al., 
Table 2. Chemical mechanisms for $\mathrm{CH}_{3} \mathrm{C}(\mathrm{O}) \mathrm{O}_{2}$ and $\mathrm{CH}_{3} \mathrm{O}_{2}$ related chemistry modified or added to MCMv3.3.1.

\begin{tabular}{|c|c|c|}
\hline Reactions & $\begin{array}{r}\text { Rate constants } \\
\left(\mathrm{cm}^{3} \text { molecule }^{-1} \mathrm{~s}^{-1}\right)\end{array}$ & Reference \\
\hline \multicolumn{3}{|l|}{$\mathrm{CH}_{3} \mathrm{C}(\mathrm{O}) \mathrm{O}_{2}$ chemistry } \\
\hline $\begin{array}{l}\mathrm{CH}_{3} \mathrm{C}(\mathrm{O}) \mathrm{O}_{2}+\mathrm{HO}_{2} \rightarrow \mathrm{CH}_{3} \mathrm{C}(\mathrm{O}) \mathrm{OOH}+\mathrm{O}_{2} \\
\mathrm{CH}_{3} \mathrm{C}(\mathrm{O}) \mathrm{O}_{2}+\mathrm{HO}_{2} \rightarrow \mathrm{CH}_{3} \mathrm{C}(\mathrm{O}) \mathrm{OH}+\mathrm{O}_{3} \\
\mathrm{CH}_{3} \mathrm{C}(\mathrm{O}) \mathrm{O}_{2}+\mathrm{HO}_{2} \rightarrow \mathrm{CH}_{3}+\mathrm{CO}_{2}+\mathrm{OH}+\mathrm{O}_{2}\end{array}$ & $\begin{array}{l}2.40 \times 10^{-11} \times 0.37 \\
2.40 \times 10^{-11} \times 0.12 \\
2.40 \times 10^{-11} \times 0.51\end{array}$ & $\begin{array}{l}\text { Winiberg et al. (2016) } \\
\text { Winiberg et al. (2016) } \\
\text { Winiberg et al. (2016) }\end{array}$ \\
\hline \multicolumn{3}{|l|}{$\mathrm{CH}_{3} \mathrm{O}_{2}$ chemistry } \\
\hline $\mathrm{CH}_{3} \mathrm{O}_{2}+\mathrm{OH} \rightarrow$ PRODUCT & $2.80 \times 10^{-10}$ & Fittschen et al. (2014) \\
\hline
\end{tabular}

2014). As shown in Fig. 3, the model run containing newly proposed mechanisms did not have a remarkable influence on the simulated results of $\mathrm{H}_{2} \mathrm{O}_{2}$ in comparison to the model base case. But a slight difference of up to $\sim 20 \%$ between calculated and observed MHP can be noted at night, resulting from the additional removal pathway of $\mathrm{CH}_{3} \mathrm{O}_{2}$ radicals from the noon to the sunset. The increase of over $70 \%$ in rate constant and the reduction of about $10 \%$ in the branching ratio of the reaction $\mathrm{CH}_{3} \mathrm{C}(\mathrm{O}) \mathrm{O}_{2}+\mathrm{HO}_{2} \rightarrow \mathrm{CH}_{3} \mathrm{C}(\mathrm{O}) \mathrm{OOH}$ generated systematically 1.5 times higher PAA concentration in this model scenario than that in the model base case. Nevertheless, although the modeled PAA during the Phase II can be raised close to the level of the observation, the concentrations of atmospheric peroxides were not fully captured by the model with the implementation of newly proposed mechanisms (Fig. 3). The additional chemical mechanisms embedded in the model only have a marginal impact that is not sufficient to match the observed peroxides in the atmosphere. The efficient source or sink for the reproduction of the observation will be deeply investigated below.

As outlined in the introduction, the sources of $\mathrm{H}_{2} \mathrm{O}_{2}$, MHP and PAA are the direct emission from biomass burning and the photochemical oxidation of VOC precursors via $\mathrm{HO}_{2}$, $\mathrm{CH}_{3} \mathrm{O}_{2}$ and $\mathrm{CH}_{3} \mathrm{C}(\mathrm{O}) \mathrm{O}_{2}$ formation. However, it is still difficult to determine the contributions of VOC precursors at a species level. Here, to gain further insight into the secondary chemical transformation of atmospheric peroxides at Wangdu site, the sensitivity study was conducted to track out the major VOC precursors of atmospheric peroxides. An indirect approach referring to the relative incremental reactivity (RIR) concept for ozone formation in Cardelino and Chameides (1995) was adopted for the sensitivity study using the numerical model with the application of the MCMv3.3.1. MCM describes the explicit degradations of individual VOC species, and hence facilitates to quantify the role of VOC in the secondary formation of atmospheric peroxides at a species level. In this work, the definition of RIR is the ratio of reduction in the production rates of atmospheric peroxides to the reduction of VOC precursor abundances by $25 \%$ compared to the model base case, which can be regarded as a proxy for the influence of a specific VOC on the in situ for- mation of atmospheric peroxides. Phase I and Phase III were selected for the analysis, while the Phase II was precluded from the analysis as it was affected by the local emission not included in the model base case.

Figure 5 displays the average RIRs of $\mathrm{H}_{2} \mathrm{O}_{2}, \mathrm{MHP}$ and PAA for alkane, alkene, aromatic and $\mathrm{NO}_{x}$ classes as well as the seven most important individual VOC precursors. The results demonstrate that the formation of $\mathrm{H}_{2} \mathrm{O}_{2}$ was sensitive to alkenes and insensitive to alkanes, aromatics and $\mathrm{NO}_{x}$. The production of MHP and PAA shows a strong dependence on alkenes and $\mathrm{NO}_{x}$, while it is relatively independent of aromatics and alkanes other than methane. Isoprene and trans-2-butene turn out to be the key VOC species controlling the formation of atmospheric peroxides. Moreover, cis2-butene, cis-2-pentene, propene and 1,2,4-trimethylbenzene also seem to be the major individual VOC precursors as evidence by Fig. 5. Methane is noticed to be an important contributor to the formation of MHP. Such a list of VOC species is not consistent with our previous studies over urban Beijing that suggested aromatic (i.e., toluene and dialkylbenzenes) as the dominant VOC precursor of atmospheric peroxides (Zhang et al., 2010; Liang et al., 2013b). It reflects that the relative significance of individual VOC precursors varies from place to place. The distinction between the two sites is attributable to the relatively more abundant isoprene, anthropogenic alkenes and much less reactive aromatics at the rural site in the NCP than those at the urban site, Beijing.

With the identification of a small class of key VOC precursors contributing to the formation of peroxides in the atmosphere of NCP, the effective control strategies for mitigating the pollution resulted from atmospheric peroxides can be formulated. In the NCP, it has been revealed that the vehicular exhaust is the predominant source responsible for the VOC species such as propene, trans/cis-2-butene and trimethylbenzene in the surrounding areas of the observation site (Yuan et al., 2009; Ran et al., 2011; M. Li et al., 2014; Li et al., 2015; Wu et al., 2016), while the vegetation governs the release of isoprene. It is recommended to take measures for vehicle emission control and land use management (e.g., modifying the amount and types of vegetation) in order to mitigate the pollution of atmospheric peroxides in the NCP 

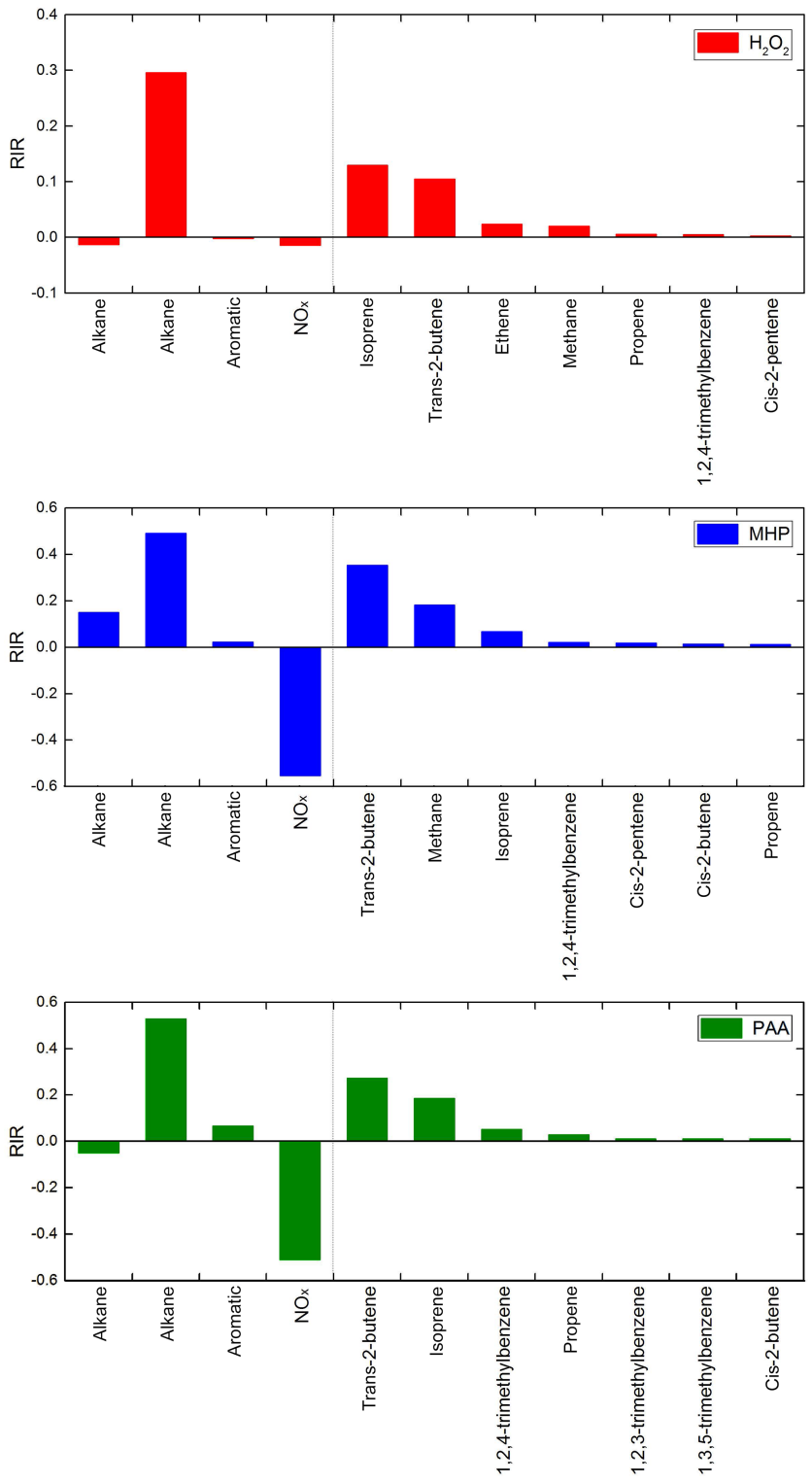

Figure 5. Sensitivity of production rates of atmospheric peroxides to major VOC precursor groups and individual VOC species for Phase I and Phase III.

and hence alleviate their potential harmful effects on air quality, human health and ecosystem.

\subsection{Direct production of peroxides from biomass burning}

In the Phase II, the levels of $\mathrm{H}_{2} \mathrm{O}_{2}$, MHP and PAA were highly elevated in comparison with the other phases, which could not be explained by the photochemical process in the model base case alone. It provides a hint that an additional formation pathway is required to improve the results of model simulation. In Sect. 3.2, we hypothesized that the direct production of peroxides from biomass burn- ing should serve as an essential source for the unexpected burst of atmospheric peroxides. Here, we tested the hypothesis by means of the box model and linear regression with the observation data from three events mentioned below during the Phase II. It is well known that $\mathrm{CO}$ and $\mathrm{K}^{+}$can be used as the reference for the biomass combustion (Koppmann et al., 2005; Reid et al., 2005; Li et al., 2007; Sullivan et al., 2008; Cheng et al., 2013, 2014; J. F. Li et al., 2014; Wang et al., 2015). The averaged CO levels were $0.42 \pm$ $0.16,0.79 \pm 0.20$ and $0.61 \pm 0.20 \mathrm{ppmv}$ for the Phase I, Phase II and Phase III, respectively. The mean $\mathrm{K}^{+}$concentrations were about $0.64 \pm 1.19 \mu \mathrm{g} \mathrm{m}^{-3}$ for the Phase I, $2.51 \pm 1.53 \mu \mathrm{g} \mathrm{m}^{-3}$ for the Phase II and $0.26 \pm 0.21 \mu \mathrm{g} \mathrm{m}^{-3}$ for the Phase III. The abundances of $\mathrm{CO}$ and $\mathrm{K}^{+}$during the Phase II were higher than that during the Phase I and Phase III, which is consistent with the observed intensive biomass burning activities at Wangdu site (Ye, 2015). Nevertheless, in addition to the biomass burning, $\mathrm{CO}$ level in the NCP was also affected by anthropogenic activities with the regional transport of polluted air masses, for example, the urban plumes. It has been proved that airborne $\mathrm{K}^{+}$is acceptable as the tracer for biomass burning during summertime in the NCP (Cheng et al., 2013; Wang et al., 2015). The concentrations of $\mathrm{CH}_{3} \mathrm{CN}$, another tracer for biomass burning, measured by Proton-transfer-reaction mass spectrometry (PTRMS) exhibited similar temporal variation to the concentrations of $\mathrm{K}^{+}$during the Wangdu campaign 2014 except on 10 June (X. Huang, personal communication, 2015). Therefore, $\mathrm{K}^{+}$might be a better indicator of biomass burning than $\mathrm{CO}$ here. In the Phase II, we identified several biomass burning events with concentrations of $\mathrm{K}^{+}$more than twice the mean value of that in the Phase I and Phase III. Considering the availability of the observation data for atmospheric peroxides, we focused our analysis on three events as follows: Event I (17:00-20:00 on 15 June), Event II (16:00-19:00 on 16 June) and Event III (12:00-15:00 on 17 June) with durations of over $3 \mathrm{~h}$.

As illustrated in Fig. 3, the model base case cannot reproduce the measurements for atmospheric peroxides in the three events. To match the observations, the primary sources for $\mathrm{H}_{2} \mathrm{O}_{2}$, MHP and PAA were applied to our model. The strengths of the primary sources for $\mathrm{H}_{2} \mathrm{O}_{2}$, MHP and PAA quantified by the difference between modeled and measured peroxide concentrations were about $0.25-1.80,0.24-0.44$ and $0.02-0.16 \mathrm{ppbv} \mathrm{h}^{-1}$, respectively. These values were on the order of the known secondary production rates of atmospheric peroxides during the three events. The impact of the primary sources of peroxides on $\mathrm{HO}_{x}$ radicals was limited with the increase of $\mathrm{OH}$ radicals not more than $10 \%$ and the increase of $\mathrm{HO}_{2}$ radicals not more than $5 \%$. It should be pointed out that the estimation was associated with large uncertainties since it did not include the heterogeneous uptake of peroxides by aerosols in the model here. In view of the possible additional sink for atmospheric peroxides as discussed in Sect. 3.4 below, the primary sources for $\mathrm{H}_{2} \mathrm{O}_{2}$, 
Table 3. Linear regression of atmospheric peroxide species to $\mathrm{CO}$ and $\mathrm{K}^{+}$for three biomass burning events during the Phase II (15-17 June). Correlation coefficients shown in italic and bold indicate statistical significance $(p<0.05)$ and higher statistical significance $(p<0.01)$, respectively.

\begin{tabular}{lccccc}
\hline \multirow{2}{*}{ Species } & Slope $^{\mathrm{a}}$ & \multicolumn{2}{c}{ Correlation coefficient } & $N^{\mathrm{b}}$ & $\begin{array}{r}\text { Critical correlation } \\
\text { coefficient }\end{array}$ \\
\cline { 3 - 4 } & & $\mathrm{CO}$ & $\mathrm{K}^{+}$ & & \\
\hline Event I & & & & & \\
\hline $\mathrm{H}_{2} \mathrm{O}_{2}$ & $2.17 \times 10^{-3}$ & $\mathbf{0 . 8 1 4 4}$ & $\mathbf{0 . 8 4 3 2}$ & 10 & $0.7646(p<0.01)$, \\
$\mathrm{MHP}$ & $1.23 \times 10^{-3}$ & 0.6873 & 0.7624 & 10 & $0.6319(p<0.05)$ \\
$\mathrm{PAA}$ & $7.16 \times 10^{-4}$ & $\mathbf{0 . 8 3 7 8}$ & $\mathbf{0 . 9 5 1 5}$ & 10 & \\
\hline Event II & & & & & \\
\hline $\mathrm{H}_{2} \mathrm{O}_{2}$ & $\mathrm{NA}^{\mathrm{c}}$ & $\mathrm{NA}^{\mathrm{c}}$ & $\mathbf{0 . 9 3 9 4}$ & 12 & $0.7079(p<0.01)$, \\
$\mathrm{MHP}$ & $\mathrm{NA}^{\mathrm{c}}$ & $\mathrm{NA}^{\mathrm{c}}$ & $\mathbf{0 . 9 4 9 1}$ & 12 & $0.5760(p<0.05)$ \\
PAA & $\mathrm{NA}^{\mathrm{c}}$ & $\mathrm{NA}^{\mathrm{c}}$ & $\mathbf{0 . 9 4 4 9}$ & 12 & \\
\hline Event III & & & & & \\
\hline $\mathrm{H}_{2} \mathrm{O}_{2}$ & $\mathrm{NA}^{\mathrm{c}}$ & $\mathrm{NA}^{\mathrm{c}}$ & $\mathbf{0 . 9 6 3 2}$ & 9 & $0.7977(p<0.01)$, \\
$\mathrm{MHP}$ & $\mathrm{NA}^{\mathrm{c}}$ & $\mathrm{NA}^{\mathrm{c}}$ & $\mathbf{0 . 8 7 4 1}$ & 9 & $0.6664(p<0.05)$ \\
PAA & $\mathrm{NA}^{\mathrm{c}}$ & $\mathrm{NA}^{\mathrm{c}}$ & $\mathbf{0 . 8 4 3 6}$ & 9 & \\
\hline
\end{tabular}

${ }^{\text {a }}$ Slope: enhancement ratio of speciated peroxides relative to $\mathrm{CO} .{ }^{\mathrm{b}} \mathrm{N}$ : number of samples. ${ }^{\mathrm{c}} \mathrm{NA}$ : missing data.

MHP and PAA might represent the lower limit. The effect of biomass burning on the levels of atmospheric peroxides might be underestimated as well. We underscore that there might exist even larger missing sources for $\mathrm{H}_{2} \mathrm{O}_{2}$, MHP and PAA due to the scarcity of some important removal pathways of atmospheric peroxides in the model in this section.

The results of linear regression involving correlation coefficients and their statistical significance of $\mathrm{H}_{2} \mathrm{O}_{2}$, MHP and PAA to $\mathrm{CO}$ and $\mathrm{K}^{+}$were listed in Table 3 for the three biomass burning events. The relationships between atmospheric peroxides and biomass burning indicators were analyzed separately for each event owing to the variability of fire emissions. A notable trend between atmospheric peroxides and $\mathrm{K}^{+}$was found with correlation coefficients exceeding the significance threshold, which provided a convincing evidence for the direct production of peroxides from biomass burning as the additional source. Moreover, it was noticed that $\mathrm{CO}$ agreed well with $\mathrm{K}^{+}$for the Event I, exhibiting excellent correlation with atmospheric peroxides (Table 3 ). The enhancement ratios of $\mathrm{H}_{2} \mathrm{O}_{2}$, MHP and PAA relative to $\mathrm{CO}$ were calculated to be at the magnitude of $10^{-3}$, which are similar to the enhancement signals of atmospheric peroxides to $\mathrm{CO}$ obtained near biomass fires from flights published by Lee et al. (1997).

It is noteworthy that several other chemical processes, for example, secondary formation via the photooxidation of potential unmeasured short-lived VOC species emitted from biomass fires prior to our sampling of the plume at the observational site are alternatives to the direct production from biomass burning as the missing source of atmospheric per- oxides in the model. Thus, it appears necessary and desirable to further distinguish the extent to which atmospheric peroxides are generated via the direct production or secondary formation from biomass burning in future research. Laboratory studies are required to simulate the biomass fires in the NCP using combustion chamber to critically characterize the emission factors of atmospheric peroxides to $\mathrm{CO}$ and determine their generation mechanisms. Also, more reliable aircraft and ground-based field measurements for the variation of atmospheric peroxides during the harvest seasons in China need to be carried out and would help to shed some light on the role of biomass burning in the abundance of peroxides in the atmosphere.

\subsection{Heterogeneous uptake of peroxides by aerosol}

In Sect. 3.2, heterogeneous uptake on atmospheric particles was considered as a suitable explanation for the missing sink for $\mathrm{H}_{2} \mathrm{O}_{2}$, MHP and PAA during the Phase I and Phase III in view of substantial aerosol loading in the NCP that provided considerable sites for heterogeneous reactions. Here, we made an attempt to implement a parameterization of heterogeneous uptake by aerosols in our box model to resolve the deviation between the simulated and observed data (see Sect. 2.3). Using the uptake coefficient of $1 \times 10^{-3}$ for $\mathrm{H}_{2} \mathrm{O}_{2}$, MHP and PAA, a good agreement between the modeled and measured temporal variation of atmospheric peroxides can be obtained in Phase I and Phase III by taking into account the combined model-measurement error that was conservatively assumed to be $\sim 50 \%$ (Fig. 3). The modeled and mea- 
sured shape of the diurnal cycle of $\mathrm{H}_{2} \mathrm{O}_{2}$ in the Phase $\mathrm{I}$ and the Phase III were similar. The calculated $\mathrm{H}_{2} \mathrm{O}_{2}$, MHP and PAA with the coupling of the heterogeneous reaction were on average decreased by about $75 \%$ compared to the results in the model base case during the Phase III. The uptake coefficient of $1 \times 10^{-3}$ approached the upper limit of the laboratory measured value for $\mathrm{H}_{2} \mathrm{O}_{2}$ on mineral dust $\left(9 \times 10^{-4}\right)$ reported by Pradhan et al. (2010), but a little higher than the previous measured values on ambient $\mathrm{PM}_{2.5}$ of $(1-5) \times 10^{-4}$ during the summertime over urban Beijing (Wu et al., 2015). It is reasonable as $\mathrm{Wu}$ et al. (2015) pointed out that the uptake coefficients for $\mathrm{H}_{2} \mathrm{O}_{2}$ and organic peroxides on ambient $\mathrm{PM}_{2.5}$ are in the same range and show no obvious differences between daytime and nighttime or between non-hazy and hazy conditions.

With the adoption of heterogeneous uptake coefficient of $1 \times 10^{-3}$, we evaluated the sinks of atmospheric peroxides in the Phase I and Phase III that represented non-haze and haze conditions, respectively. The mean surface area concentrations that were corrected for the hygroscopic growth of aerosol were measured to be $968 \mu^{2} \mathrm{~cm}^{-3}$ for Phase I and $1491 \mu \mathrm{m}^{2} \mathrm{~cm}^{-3}$ for Phase III. Figure 6 demonstrated that the destruction of atmospheric peroxides during the two phases originated from a diversity of sinks, including photolysis, $\mathrm{OH}$-initiated reaction, dry deposition and heterogeneous uptake. It has been reported that the heterogeneous reaction is the most important sink for $\mathrm{H}_{2} \mathrm{O}_{2}$ in urban (Liang et al., 2013b) and suburban areas (Guo et al., 2014). In contrast, $\mathrm{OH}$-initiated reaction and dry deposition were regarded as the major removal pathways of organic peroxides in rural (Zhang et al., 2012) and forests areas (Nguyen et al., 2015). Here, heterogeneous uptake by aerosols turned out to be the predominant sink for atmospheric peroxides in the NCP, accounting for more than $60 \%$ of the total loss, while dry deposition became the marginal removal pathway that contributed $\sim 10 \%$ to the destruction of $\mathrm{H}_{2} \mathrm{O}_{2}$, MHP and PAA. The role of OH-initiated reaction in the total loss varied between the speciated peroxides with no more than $30 \%$. Photolysis only represented a minor contribution $(<3 \%)$. The most prominent feature on haze days was the larger loss of atmospheric peroxides via heterogeneous process, demonstrating the enhanced impact of aerosols on the sink of peroxides during the haze episode compared to that during the non-haze episode.

On the basis of the analysis above, we investigated the atmospheric lifetime of peroxides in the NCP with the integration of observation and modeling. The lifetime of $\mathrm{H}_{2} \mathrm{O}_{2}$, MHP and PAA were estimated with the concentration-totime curves between 18:00 and 24:00 LT as the formation of atmospheric peroxides was weak and negligible during this phase. The average lifetime obtained from the field observation between 18:00 and 24:00 LT in the Phase I was around 4.0, 5.6 and $3.1 \mathrm{~h}$ for $\mathrm{H}_{2} \mathrm{O}_{2}$, MHP and PAA, respectively, which was similar to the values between 18:00 and 24:00 LT in the Phase $\mathrm{I}$ of 3.4, 4.3 and $5.2 \mathrm{~h}$ for $\mathrm{H}_{2} \mathrm{O}_{2}$, MHP and PAA, respectively, given by our model simula-
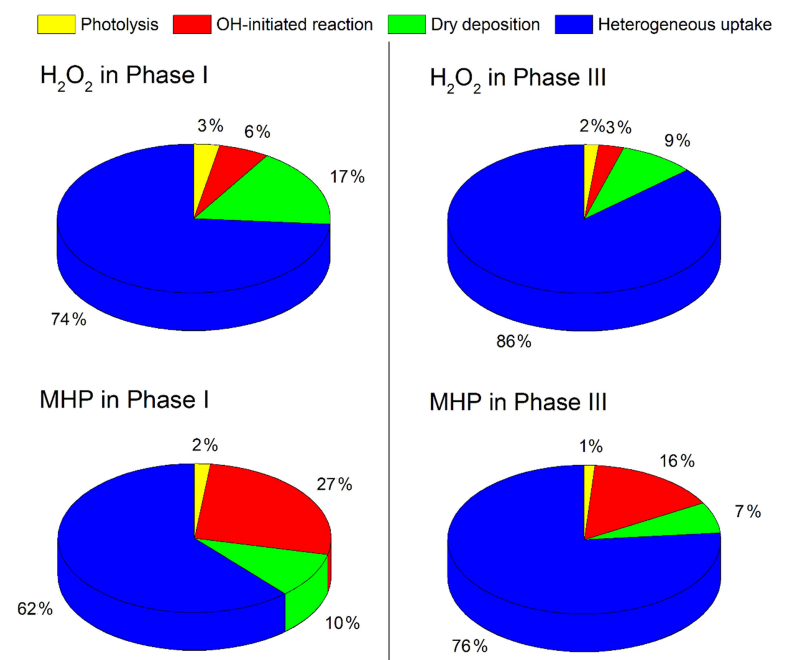

MHP in Phase III
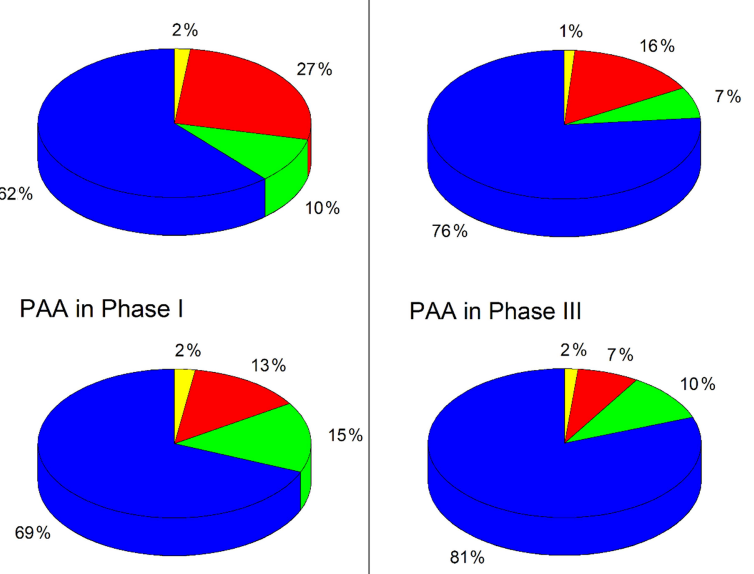

Figure 6. Contributions of each sink to $\mathrm{H}_{2} \mathrm{O}_{2}, \mathrm{MHP}$ and PAA destruction in the box model with the heterogeneous uptake by aerosols added during Phase I and Phase III.

tion. The daily-averaged lifetime of atmospheric peroxides in the Phase III was $\sim 40 \%$ smaller than that in the Phase I. Using the box model, the daily-averaged lifetime of atmospheric $\mathrm{H}_{2} \mathrm{O}_{2}$, MHP and PAA during the whole of Phase I and Phase III were calculated to be about 2.1, 2.3 and $3.0 \mathrm{~h}$, respectively. This is comparable to the literature results with the inclusion of heterogeneous reaction (Liang et al., 2013b; Wu et al., 2015), but notably shorter than the recent studies conducted by Khan et al. (2015) and Nguyen et al. (2015) without the coupling of the heterogeneous process. Although dry deposition is thought to dominate the atmospheric lifetime of peroxides in previous studies (Reeves and Penkett, 2003), its role in the lifetime of atmospheric peroxides is insignificant during Wangdu Campaign 2014. The sensitivity of modeled relative loss of dry deposition to the uncertainties in the planetary boundary layer height was low as the contribution of dry deposition to the loss of $\mathrm{H}_{2} \mathrm{O}_{2}$ in Phase I decreased no more than $10 \%$ with the PBL height doubled. The simulated daily-averaged lifetime of atmospheric peroxides can be over $10 \mathrm{~h}$ by supposing that the loss of $\mathrm{H}_{2} \mathrm{O}_{2}$, MHP and PAA is merely due to photolysis, $\mathrm{OH}$-initiated reaction and dry deposition. It emphasizes that heterogeneous uptake on aerosols determines the atmospheric lifetime of peroxides. 
It is worth noting that the heterogeneous uptake of peroxides by aerosols in the atmospheric chemical model is still controversial as it is possible that the aerosol uptake of $\mathrm{HO}_{2}$ radicals is the explanation for the missing sink. This raises an interesting question of whether $\mathrm{HO}_{2}$ uptake or peroxide uptake is responsible for the imbalance between observation and modeling. It has been inferred by formerly published literature that aerosol uptake of $\mathrm{HO}_{2}$ radicals is the major reason for the overprediction of the levels of atmospheric peroxides in the model (de Reus et al., 2005; Mao et al., 2013; Guo et al., 2014). Nevertheless, it is apparent that the extent of $\mathrm{HO}_{2}$ heterogeneous degradation depends on the atmospheric environment, especially the concentration and property of aerosol particles that vary under different conditions. The measured $\mathrm{HO}_{2}$ concentrations at Wangdu site are close to the modeled $\mathrm{HO}_{2}$ concentrations by the box model merely with the gas-phase regional atmospheric chemical mechanism (RACM) comprised (K. Lu, personal communication, 2015). Hence, the impact of aerosol uptake of $\mathrm{HO}_{2}$ radicals on the concentration of atmospheric peroxides is insignificant during Wangdu Campaign 2014 and not taken into account in our model, while heterogeneous uptake of atmospheric peroxides by aerosols is exclusively adopted to improve the reproduction of the observation in the two phases above.

It has been inferred that heterogeneous uptake of peroxides on ambient $\mathrm{PM}_{2.5}$ probably results from solid surface reactions and aerosol aqueous reactions (Wu et al., 2015), for instance, "Fenton-like" reactions between peroxides and transition metal ions, which is supported by the laboratory studies (Chevallier et al., 2004; Deguillaume et al., 2005) and field observations (Liang et al., 2013b; Guo et al., 2014). Nevertheless, the detailed heterogeneous mechanism containing individual reaction channels was not included in the present work owing to the chemical complexity of the ambient aerosol. Given the potential importance of atmospheric peroxide compounds on the generation of $\mathrm{HO}_{x}$ radicals and aerosol ROS, the aging of mineral dust and SOA and the formation of haze (Huang et al., 2015; Pöschl and Shiraiwa, 2015; Zhang et al., 2015; Li et al., 2016), more comprehensive investigations including laboratory, field and modeling studies on the heterogeneous uptake processes of $\mathrm{H}_{2} \mathrm{O}_{2}$, MHP, PAA and other peroxides are indispensable to provide concrete evidence to elucidate the chemical budget of atmospheric peroxides in the future.

\section{Conclusions}

Atmospheric peroxides including $\mathrm{H}_{2} \mathrm{O}_{2}$, MHP and PAA were measured at a rural site during the Wangdu Campaign 2014. The maximum $\mathrm{H}_{2} \mathrm{O}_{2}$ concentration was observed to be 11.3 ppbv, which was the highest value compared with previous observations in China. The concentrations of atmospheric peroxides were highly elevated during the biomass burning activities, but underwent substantial decline during the haze events. With the application of an observation-based model combining measured meteorological parameters and trace gases, we analyzed the chemical budget of peroxides under biomass burning, non-haze and haze conditions. Photochemical formation of atmospheric peroxides was attributed to a small class of alkenes, while it was insensitive to alkanes and aromatics. The key VOC precursors controlling the formation of peroxide compounds were identified to be isoprene, trans/cis-2-butene, cis-2-pentene, propene and trimethylbenzene.

The base model simulation (MCMv3.3.1) underpredicted the levels of atmospheric peroxides during biomass burning events compared with the measurement. The direct production from biomass burning was regarded as the explanation for the unexpected burst of peroxides. To improve the simulated concentrations, the strengths of the primary emissions from biomass burning should be on the same order of the known secondary production rates of atmospheric peroxides. Moreover, the model base case also overpredicted the concentrations of atmospheric peroxides on haze days in comparison with the observation. The heterogeneous uptake by aerosols was suggested to be responsible for the attenuation of peroxides. The model could reproduce the observed values with the introduction of heterogeneous process using the uptake coefficient of $1 \times 10^{-3}$ for atmospheric peroxides. According to the closure between observed and calculated concentrations, the heterogeneous uptake on aerosol particles was found to be the predominant sink for atmospheric peroxides, accounting for more than $60 \%$ of the total loss, followed by the $\mathrm{OH}$-initiated reaction $(<30 \%)$ and dry deposition $(\sim 10 \%)$. The mean atmospheric lifetime of peroxides in summer in the NCP was estimated to be around several hours that was in good agreement with previous laboratory studies for the aerosol uptake of peroxides, indicating that heterogeneous reaction determines the atmospheric lifetime of peroxides.

In view of the importance of peroxides in tropospheric oxidation capacity and formation potential of secondary aerosols, more reliable investigations focused on the biomass burning emission factors and detailed heterogeneous mechanism of speciated peroxides are urgently required to further quantitatively evaluate the role of biomass burning and heterogeneous uptake in the abundance as well as budget of atmospheric peroxides and facilitate our knowledge of the formation of haze pollution.

\section{Data availability}

The research data can be accessed on request from the corresponding author (Zhongming Chen, zmchen@pku.edu.cn). 
Acknowledgements. This work was funded by the National Natural Science Foundation of China (grants 41275125, 21190051, 21190053, 21477002, and 41421064). The authors would like to thank Min Shao group (Peking University) for their VOCs data and Alfred Wiedensohler group (Leibniz Institute for Tropospheric Research) for their particle surface area concentrations data. The authors wish to gratefully thank the entire Wangdu Campaign 2014 team for the support and collaboration at Wangdu site.

Edited by: D. Heard

Reviewed by: J. Chen and one anonymous referee

\section{References}

Atkinson, R., Baulch, D. L., Cox, R. A., Crowley, J. N., Hampson, R. F., Hynes, R. G., Jenkin, M. E., Rossi, M. J., Troe, J., and IUPAC Subcommittee: Evaluated kinetic and photochemical data for atmospheric chemistry: Volume II - gas phase reactions of organic species, Atmos. Chem. Phys., 6, 3625-4055, doi:10.5194/acp-6-3625-2006, 2006.

Ayres, J. G., Borm, P., Cassee, F. R., Castranova, V., Donaldson, K., Ghio, A., Harrison, R. M., Hider, R., Kelly, F., Kooter, I. M., Maranok, F., Maynardl, R. L., Mudwaym, I., Neln A., Sioutaso, C., Smithp, S., Baeza-Squibank, A., Chon, A., Dugganq S., and Froinesn J.: Evaluating the toxicity of airborne particulate matter and nanoparticles by measuring oxidative stress potential-a workshop report and consensus statement, Inhal. Toxicol., 20, 75-99, 2008.

Bohn, B., Corlett, G. K., Gillmann, M., Sanghavi, S., Stange, G., Tensing, E., Vrekoussis, M., Bloss, W. J., Clapp, L. J., Kortner, M., Dorn, H.-P., Monks, P. S., Platt, U., Plass-Dülmer, C., Mihalopoulos, N., Heard, D. E., Clemitshaw, K. C., Meixner, F. X., Prévôt, A. S. H., and Schmitt, R.: Photolysis frequency measurement techniques: results of a comparison within the ACCENT project, Atmos. Chem. Phys., 8, 5373-5391, doi:10.5194/acp-85373-2008, 2008.

Bossolasco, A., Faragó, E. P., Schoemaecker, C., and Fittschen, C.: Rate constant of the reaction between $\mathrm{CH}_{3} \mathrm{O}_{2}$ and $\mathrm{OH}$ radicals, Chem. Phys. Lett., 593, 7-13, 2014.

Calvert, J. G., Lazrus, A., Kok, G. L., Heikes, B. G., Walega, J. G., Lind, J., and Cantrell, C. A.: Chemical mechanisms of acid generation in the troposphere, Nature, 317, 27-35, 1985.

Cardelino, C. A. and Chameides, W. L.: An observation-based model for analyzing ozone precursor relationships in the urban atmosphere, J. Air Waste Manage., 45, 161-180, 1995.

Chao, W., Hsieh, J. T., and Chang, C. H.: Direct kinetic measurement of the reaction of the simplest Criegee intermediate with water vapor, Science, 347, 751-754, 2015.

Che, H., Xia, X., Zhu, J., Li, Z., Dubovik, O., Holben, B., Goloub, P., Chen, H., Estelles, V., Cuevas-Agulló, E., Blarel, L., Wang, H., Zhao, H., Zhang, X., Wang, Y., Sun, J., Tao, R., Zhang, X., and Shi, G.: Column aerosol optical properties and aerosol radiative forcing during a serious haze-fog month over North China Plain in 2013 based on ground-based sunphotometer measurements, Atmos. Chem. Phys., 14, 2125-2138, doi:10.5194/acp14-2125-2014, 2014.

Chen, X., Aoki, M., Takami, A., Chai, F. H., and Hatakeyama, S.: Effect of ambient-level gas-phase peroxides on foliar injury, growth, and net photosynthesis in Japanese radish (Raphanus sativus), Environ. Pollut., 158, 1675-1679, 2010.

Chen, Z. M., Wang, H. L., Zhu, L. H., Wang, C. X., Jie, C. Y., and Hua, W.: Aqueous-phase ozonolysis of methacrolein and methyl vinyl ketone: a potentially important source of atmospheric aqueous oxidants, Atmos. Chem. Phys., 8, 2255-2265, doi:10.5194/acp-8-2255-2008, 2008.

Cheng, Y., Engling, G., He, K.-B., Duan, F.-K., Ma, Y.-L., Du, Z.Y., Liu, J.-M., Zheng, M., and Weber, R. J.: Biomass burning contribution to Beijing aerosol, Atmos. Chem. Phys., 13, 77657781, doi:10.5194/acp-13-7765-2013, 2013.

Cheng, Y., Engling, G., He, K. B., Duan, F. K., Du, Z. Y., Ma, Y. L., Liang, L. L., Lu, Z. F., Liu, J. M., Zheng, M., and Weber, R. J.: The characteristics of Beijing aerosol during two distinct episodes: Impacts of biomass burning and fireworks, Environ. Pollut., 185, 149-157, 2014.

Chevallier, E., Jolibois, R. D., Meunier, N., Carlier, P., and Monod, A.: "Fenton-like" reactions of methylhydroperoxide and ethylhydroperoxide with $\mathrm{Fe}^{2+}$ in liquid aerosols under tropospheric conditions, Atmos. Environ., 38, 921-933, 2004.

Deguillaume, L., Leriche, M., Desboeufs, K., Mailhot, G., George, C., and Chaumerliac, N.: Transition metals in atmospheric liquid phases: sources, reactivity, and sensitive parameters, Chem. Rev., 105, 3388-3431, 2005.

de Reus, M., Fischer, H., Sander, R., Gros, V., Kormann, R., Salisbury, G., Van Dingenen, R., Williams, J., Zöllner, M., and Lelieveld, J.: Observations and model calculations of trace gas scavenging in a dense Saharan dust plume during MINATROC, Atmos. Chem. Phys., 5, 1787-1803, doi:10.5194/acp-5-17872005, 2005.

Draxler, R. R. and Rolph, G. D.: HYSPLIT (HYbrid SingleParticle Lagrangian Integrated Trajectory) model access via NOAA ARL READY website, NOAA Air Resources Laboratory, Silver Spring, MD, available at: http://www.arl.noaa.gov/ ready/hysplit4.html (last access: 26 January 2016), 2012.

Emmerson, K. M., Carslaw, N., Carslaw, D. C., Lee, J. D., McFiggans, G., Bloss, W. J., Gravestock, T., Heard, D. E., Hopkins, J., Ingham, T., Pilling, M. J., Smith, S. C., Jacob, M., and Monks, P. S.: Free radical modelling studies during the UK TORCH Campaign in Summer 2003, Atmos. Chem. Phys., 7, 167-181, doi:10.5194/acp-7-167-2007, 2007.

Epstein, S. A., Blair, S. L., and Nizkorodov, S. A.: Direct photolysis of $\alpha$-pinene ozonolysis secondary organic aerosol: effect on particle mass and peroxide content, Environ. Sci. Technol., 48, 11251-11258, 2014.

Ervens, B., George, C., Williams, J. E., Buxton, G. V., Salmon, G. A., Bydder, M., Wilkinson, F., Dentener, F., Mirabel, P., Wolke, R., and Herrmann, H.: CAPRAM 2.4 (MODAC mechanism): an extended and condensed tropospheric aqueous phase mechanism and its application, J. Geophys. Res., 108, 4426, doi:10.1029/2002JD002202, 2003.

Fischer, H., Pozzer, A., Schmitt, T., Jöckel, P., Klippel, T., Taraborrelli, D., and Lelieveld, J.: Hydrogen peroxide in the marine boundary layer over the South Atlantic during the OOMPH cruise in March 2007, Atmos. Chem. Phys., 15, 6971-6980, doi:10.5194/acp-15-6971-2015, 2015.

Fittschen, C., Whalley, L. K., and Heard, D. E.: The reaction of $\mathrm{CH}_{3} \mathrm{O}_{2}$ radicals with $\mathrm{OH}$ radicals: a neglected sink for $\mathrm{CH}_{3} \mathrm{O}_{2}$ in 
the remote atmosphere, Environ. Sci. Technol., 48, 7700-7701, 2014.

Guo, J., Tilgner, A., Yeung, C., Wang, Z., Louie, P. K. K., Luk, C. W. Y., Xu, Z., Yuan, C., Gao, Y., Poon, S., Herrmann, H., Lee, S., Lam, K. S., and Wang, T.: Atmospheric peroxides in a polluted subtropical environment: seasonal variation, sources and sinks, and importance of heterogeneous processes, Environ. Sci. Technol., 48, 1443-1450, 2014.

He, S. Z., Chen, Z. M., Zhang, X., Zhao, Y., Huang, D. M., Zhao, J. N., Zhu, T., Hu, M., and Zeng, L. M.: Measurement of atmospheric hydrogen peroxide and organic peroxides in Beijing before and during the 2008 Olympic Games: chemical and physical factors influencing their concentrations, J. Geophys. Res., 115, D17307, doi:10.1029/2009JD013544, 2010.

Hellpointner, E. and Gäb, S.: Detection of methyl, hydroxymethyl and hydroxyethyl hydroperoxides in air and precipitation, Nature, 337, 631-634, 1989.

Hewitt, C. N. and Kok, G. L.: Formation and occurrence of organic hydroperoxides in the troposphere: laboratory and field observations, J. Atmos. Chem., 12, 181-194, 1991.

Hofzumahaus, A., Rohrer, F., Lu, K. D., Bohn, B., Brauers, T., Chang, C. C., Fuchs, H., Holland, F., Kita, K., Kondo, Y., Li, X., Lou, S. R., Shao, M., Zeng, L. M., Wahner, A., and Zhang, Y. H.: Amplified trace gas removal in the troposphere, Science, 324, 1702-1704, 2009.

Hua, W., Chen, Z. M., Jie, C. Y., Kondo, Y., Hofzumahaus, A., Takegawa, N., Chang, C. C., Lu, K. D., Miyazaki, Y., Kita, K., Wang, H. L., Zhang, Y. H., and Hu, M.: Atmospheric hydrogen peroxide and organic hydroperoxides during PRIDE-PRD'06, China: their concentration, formation mechanism and contribution to secondary aerosols, Atmos. Chem. Phys., 8, 6755-6773, doi:10.5194/acp-8-6755-2008, 2008.

Huang, D., Chen, Z. M., Zhao, Y., and Liang, H.: Newly observed peroxides and the water effect on the formation and removal of hydroxyalkyl hydroperoxides in the ozonolysis of isoprene, Atmos. Chem. Phys., 13, 5671-5683, doi:10.5194/acp-13-56712013, 2013.

Huang, L. B., Zhao, Y., Li, H., and Chen, Z. M. Kinetics of heterogeneous reaction of sulfur dioxide on authentic mineral dust: effects of relative humidity and hydrogen peroxide, Environ. Sci. Technol., 49, 10797-10805, 2015.

Huang, R. J., Zhang, Y. L., Bozzetti, C., Ho, K. F., Cao, J. J., Han, Y. M., Daellenbach, K. R., Slowik, J. G., Platt, S. M., Canonaco, F., Zotter, P., Wolf, R., Pieber, S. M., Bruns, E. A., Crippa, M., Ciarelli, G., Piazzalunga, A., Schwikowski, M., Abbaszade, G., Schnelle-Kreis, J., Zimmermann, R., An, Z., Szidat, S., Baltensperger, U., Haddad, I. E., and Prévôt A. S. H.: High secondary aerosol contribution to particulate pollution during haze events in China, Nature, 514, 218-222, 2014.

Jacob, D. J.: Heterogeneous chemistry and tropospheric ozone, Atmos. Environ., 34, 2131-2159, 2000.

Jenkin, M. E., Saunders, S. M., and Pilling, M. J.: The tropospheric degradation of volatile organic compounds: a protocol for mechanism development, Atmos. Environ., 31, 81-104, 1997.

Jenkin, M. E., Saunders, S. M., Wagner, V., and Pilling, M. J.: Protocol for the development of the Master Chemical Mechanism, MCM v3 (Part B): tropospheric degradation of aromatic volatile organic compounds, Atmos. Chem. Phys., 3, 181-193, doi:10.5194/acp-3-181-2003, 2003.
Jenkin, M. E., Young, J. C., and Rickard, A. R.: The MCM v3.3.1 degradation scheme for isoprene, Atmos. Chem. Phys., 15, 11433-11459, doi:10.5194/acp-15-11433-2015, 2015.

Khan, M. A. H., Cooke, M. C., Utembe, S. R., Xiao, P., Morris, W. C., Derwent, R. G., Archibald, A. T., Jenkin, M. E., Percival, C. J., and Shallcross, D. E.: The global budgets of organic hydroperoxides for present and pre-industrial scenarios, Atmos. Environ., 110, 65-74, 2015.

Koppmann, R., von Czapiewski, K., and Reid, J. S.: A review of biomass burning emissions, part I: gaseous emissions of carbon monoxide, methane, volatile organic compounds, and nitrogen containing compounds, Atmos. Chem. Phys. Discuss., 5, 1045510516, doi:10.5194/acpd-5-10455-2005, 2005.

Kroll, J. H. and Seinfeld, J. H.: Chemistry of secondary organic aerosol: Formation and evolution of low-volatility organics in the atmosphere, Atmos. Environ., 42, 3593-3624, 2008.

Lee, M., Heikes, B. G., Jacob, D. J., Sachse, G., and Anderson, B.: Hydrogen peroxide, organic hydroperoxide, and formaldehyde as primary pollutants from biomass burning, J. Geophys. Res., 102, 1301-1309, 1997.

Lee, M., Heikes, B. G., and Jacob, D. J.: Enhancements of hydroperoxides and formaldehyde in biomass burning impacted air and their effect on atmospheric oxidant cycles, J. Geophys. Res., 103, 13201-13212, 1998.

Lee, M., Heikes, B. G., and O'Sullivan, D. W.: Hydrogen peroxide and organic hydroperoxide in the troposphere: a review, Atmos. Environ., 34, 3475-3494, 2000.

Li, H., Chen, Z., Huang, L., and Huang, D.: Organic peroxides' gasparticle partitioning and rapid heterogeneous decomposition on secondary organic aerosol, Atmos. Chem. Phys., 16, 1837-1848, doi:10.5194/acp-16-1837-2016, 2016.

Li, J. F., Song, Y., Mao, Y., Mao, Z. C., Wu, Y. S., Li, M. M., Huang, X., He, Q. C., and Hu, M.: Chemical characteristics and source apportionment of $\mathrm{PM}_{2.5}$ during the harvest season in eastern China's agricultural regions, Atmos. Environ., 92, 442-448, 2014.

Li, L. Y., Xie, S. D., Zeng, L. M., Wu, R. R., and Li, J.: Characteristics of volatile organic compounds and their role in ground-level ozone formation in the Beijing-Tianjin-Hebei region, China, Atmos. Environ., 113, 247-254, 2015.

Li, M., Zhang, Q., Streets, D. G., He, K. B., Cheng, Y. F., Emmons, L. K., Huo, H., Kang, S. C., Lu, Z., Shao, M., Su, H., Yu, X., and Zhang, Y.: Mapping Asian anthropogenic emissions of nonmethane volatile organic compounds to multiple chemical mechanisms, Atmos. Chem. Phys., 14, 5617-5638, doi:10.5194/acp14-5617-2014, 2014.

Li, X., Rohrer, F., Brauers, T., Hofzumahaus, A., Lu, K., Shao, M., Zhang, Y. H., and Wahner, A.: Modeling of HCHO and CHO$\mathrm{CHO}$ at a semi-rural site in southern China during the PRIDEPRD2006 campaign, Atmos. Chem. Phys., 14, 12291-12305, doi:10.5194/acp-14-12291-2014, 2014.

Li, X. H., Wang, S. X., Duan, L., Hao, J. M., Li, C., Chen, Y. S., and Yang, L.: Particulate and trace gas emissions from open burning of wheat straw and corn stover in China, Environ. Sci. Technol., 41, 6052-6058, 2007.

Liang, H., Chen, Z. M., Wu, Q. Q., Huang, D., and Zhao, Y.: Do aerosols influence the diurnal variation of $\mathrm{H}_{2} \mathrm{O}_{2}$ in the atmosphere?, AGU Fall Meeting Abstracts, 9-13 December 2013, San Francisco, California, USA, A13D-0222, $2013 \mathrm{a}$. 
Liang, H., Chen, Z. M., Huang, D., Zhao, Y., and Li, Z. Y.: Impacts of aerosols on the chemistry of atmospheric trace gases: a case study of peroxides and $\mathrm{HO}_{2}$ radicals, Atmos. Chem. Phys., 13, 11259-11276, doi:10.5194/acp-13-11259-2013, 2013 b.

Liu, H. J.: Measurement of aerosol light scattering enhancement factor and study on hygroscopicity parameter, $\mathrm{PhD}$, thesis, Peking University, China, 2015.

Liu, Y., Yuan, B., Li, X., Shao, M., Lu, S., Li, Y., Chang, C.C., Wang, Z., Hu, W., Huang, X., He, L., Zeng, L., Hu, M., and Zhu, T.: Impact of pollution controls in Beijing on atmospheric oxygenated volatile organic compounds (OVOCs) during the 2008 Olympic Games: observation and modeling implications, Atmos. Chem. Phys., 15, 3045-3062, doi:10.5194/acp15-3045-2015, 2015.

Liu, Y. H., Lu, K. D., Dong, H. B., Li, X., Cheng, P., Zou, Q., Wu, Y. S., Liu, X. G., and Zhang, Y. H.: In situ monitoring of atmospheric nitrous acid based on multi-pumping flow system and liquid waveguide capillary cell, J. Environ. Sci., 43, 273-284, 2016.

Lu, K. D., Rohrer, F., Holland, F., Fuchs, H., Bohn, B., Brauers, T., Chang, C. C., Häseler, R., Hu, M., Kita, K., Kondo, Y., Li, X., Lou, S. R., Nehr, S., Shao, M., Zeng, L. M., Wahner, A., Zhang, Y. H., and Hofzumahaus, A.: Observation and modelling of $\mathrm{OH}$ and $\mathrm{HO}_{2}$ concentrations in the Pearl River Delta 2006: a missing $\mathrm{OH}$ source in a VOC rich atmosphere, Atmos. Chem. Phys., 12, 1541-1569, doi:10.5194/acp-12-1541-2012, 2012.

Madronich, S.: The Tropospheric visible Ultra-violet (TUV) model web page, available at: http://www2.acom.ucar.edu/modeling/ tuv (last access: 21 January 2016), 2002.

Mao, J., Jacob, D. J., Evans, M. J., Olson, J. R., Ren, X., Brune, W. H., Clair, J. M. St., Crounse, J. D., Spencer, K. M., Beaver, M. R., Wennberg, P. O., Cubison, M. J., Jimenez, J. L., Fried, A., Weibring, P., Walega, J. G., Hall, S. R., Weinheimer, A. J., Cohen, R. C., Chen, G., Crawford, J. H., McNaughton, C., Clarke, A. D., Jaeglé, L., Fisher, J. A., Yantosca, R. M., Le Sager, P., and Carouge, C.: Chemistry of hydrogen oxide radicals $\left(\mathrm{HO}_{x}\right)$ in the Arctic troposphere in spring, Atmos. Chem. Phys., 10, 58235838, doi:10.5194/acp-10-5823-2010, 2010.

Mao, J., Fan, S., Jacob, D. J., and Travis, K. R.: Radical loss in the atmosphere from $\mathrm{Cu}-\mathrm{Fe}$ redox coupling in aerosols, Atmos. Chem. Phys., 13, 509-519, doi:10.5194/acp-13-509-2013, 2013.

Neeb, P., Sauer, F., Horie, O., and Moortgat, G. K.: Formation of hydroxymethyl hydroperoxide and formic acid in alkene ozonolysis in the presence of water vapour, Atmos. Environ., 31, 14171423, 1997.

Nguyen, T. B., Crounse, J. D., Teng, A. P., Clair, J. M. S., Paulot, F., Wolfe, G. M., and Wennberg, P. O.: Rapid deposition of oxidized biogenic compounds to a temperate forest, P. Natl. Acad. Sci., 112, E392-E401, 2015.

Pöschl, U. and Shiraiwa, M.: Multiphase chemistry at the atmosphere-biosphere interface influencing climate and public health in the anthropocene, Chem. Rev., 115, 4440-4475, 2015.

Pradhan, M., Kyriakou, G., Archibald, A. T., Papageorgiou, A. C., Kalberer, M., and Lambert, R. M.: Heterogeneous uptake of gaseous hydrogen peroxide by Gobi and Saharan dust aerosols: a potential missing sink for $\mathrm{H}_{2} \mathrm{O}_{2}$ in the troposphere, Atmos. Chem. Phys., 10, 7127-7136, doi:10.5194/acp-10-7127-2010, 2010.
Ran, L., Zhao, C. S., Xu, W. Y., Lu, X. Q., Han, M., Lin, W. L., Yan, P., Xu, X. B., Deng, Z. Z., Ma, N., Liu, P. F., Yu, J., Liang, W. D., and Chen, L. L.: VOC reactivity and its effect on ozone production during the HaChi summer campaign, Atmos. Chem. Phys., 11, 4657-4667, doi:10.5194/acp-11-4657-2011, 2011.

Reeves, C. E. and Penkett, S. A.: Measurements of peroxides and what they tell us, Chem. Rev., 103, 5199-5218, 2003.

Reid, J. S., Koppmann, R., Eck, T. F., and Eleuterio, D. P.: A review of biomass burning emissions part II: intensive physical properties of biomass burning particles, Atmos. Chem. Phys., 5, 799825, doi:10.5194/acp-5-799-2005, 2005.

Sander, S. P., Abbatt, J., Barker, J. R., Burkholder, J. B., Friedl, R. R., Golden, D. M., Huie, R. E., Kolb, C. E., Kurylo, M. J., Moortgat, G. K., Orkin, V. L., and Wine, P. H.: Chemical kinetics and photochemical data for use in atmospheric studies, Evaluation No. 17, JPL Publication 10-6, Jet Propulsion Laboratory, Pasadena, CA, USA, available at: http://jpldataeval.jpl.nasa.gov (last access: 1 February 2016), 2011.

Sarwar, G., Godowitch, J., Henderson, B. H., Fahey, K., Pouliot, G., Hutzell, W. T., Mathur, R., Kang, D., Goliff, W. S., and Stockwell, W. R.: A comparison of atmospheric composition using the Carbon Bond and Regional Atmospheric Chemistry Mechanisms, Atmos. Chem. Phys., 13, 9695-9712, doi:10.5194/acp13-9695-2013, 2013.

Sauer, F., Beck, J., Schuster, G., and Moortgat, G. K.: Hydrogen peroxide, organic peroxides and organic acids in a forested area during FIELDVOC'94, Chemosphere, 3, 309-326, 2001.

Saunders, S. M., Jenkin, M. E., Derwent, R. G., and Pilling, M. J.: Protocol for the development of the Master Chemical Mechanism, MCM v3 (Part A): tropospheric degradation of nonaromatic volatile organic compounds, Atmos. Chem. Phys., 3, 161-180, doi:10.5194/acp-3-161-2003, 2003.

Seinfeld, J. H. and Pandis, S. N.: Atmospheric Chemistry and Physics: From Air Pollution to Climate Change, John Wiley \& Sons, New York, USA, 2006.

Stein, A. F. and Saylor, R. D.: Sensitivities of sulfate aerosol formation and oxidation pathways on the chemical mechanism employed in simulations, Atmos. Chem. Phys., 12, 8567-8574, doi:10.5194/acp-12-8567-2012, 2012.

Sullivan, A. P., Holden, A. S., Patterson, L. A., McMeeking, G. R., Kreidenweis, S. M., Malm, W. C., Hao, W. M., Wold, C. E., and Collett, J. L.: A method for smoke marker measurements and its potential application for determining the contribution of biomass burning from wildfires and prescribed fires to ambient $\mathrm{PM}_{2.5}$ organic carbon, J. Geophys. Res., 113, D22302, doi:10.1029/2008JD010216, 2008.

Tan, Z. F., Fuchs, H., Lu, K. D., Bohn, B., Broch, S., Haeseler, R., Hofzumahaus, A., Holland, F., Li, X., Liu, Y., Rohrer, F., Shao, M., Wang, B. L., Wang, M., Wu, Y. S., Zeng, L. M., Wahner, A., and Zhang, Y. H.: Observation and modelling of the $\mathrm{OH}, \mathrm{HO}_{2}$ and $\mathrm{RO}_{2}$ radicals at a rural site (Wangdu) in the North China Plain in summer 2014, Geophysical Research Abstracts, Vienna, Austria, EGU2016-5459, 2016.

Tao, M. H., Chen, L. F., Su, L., and Tao, J. H.: Satellite observation of regional haze pollution over the North China Plain, J. Geophys. Res., 117, D12203, doi:10.1029/2012JD017915, 2012.

Wang, H. L., Huang, D., Zhang, X., Zhao, Y., and Chen, Z. M.: Understanding the aqueous phase ozonolysis of isoprene: distinct product distribution and mechanism from the gas phase reaction, 
Atmos. Chem. Phys., 12, 7187-7198, doi:10.5194/acp-12-71872012, 2012.

Wang, L. L., Xin, J. Y., Li, X. R., and Wang, Y. S.: The variability of biomass burning and its influence on regional aerosol properties during the wheat harvest season in North China, Atmos. Res., 157, 153-163, 2015.

Wang, M., Zeng, L. M., Lu, S. H., Shao, M., Liu, X. L., Yu, X. N., Chen, W. T., Yuan, B., Zhang, Q., Hu, M., and Zhang, Z. Y.: Development and validation of a cryogen-free automatic gas chromatograph system (GC-MS/FID) for online measurements of volatile organic compounds, Anal. Methods, 6, 9424-9434, 2014.

Winiberg, F. A. F., Dillon, T. J., Orr, S. C., Groß, C. B. M., Bejan, I., Brumby, C. A., Evans, M. J., Smith, S. C., Heard, D. E., and Seakins, P. W.: Direct measurements of $\mathrm{OH}$ and other product yields from the $\mathrm{HO}_{2}+\mathrm{CH}_{3} \mathrm{C}(\mathrm{O}) \mathrm{O}_{2}$ reaction, Atmos. Chem. Phys., 16, 4023-4042, doi:10.5194/acp-16-4023-2016, 2016.

Wu, Q. Q., Huang, L. B., Liang, H., Zhao, Y., Huang, D., and Chen, Z. M.: Heterogeneous reaction of peroxyacetic acid and hydrogen peroxide on ambient aerosol particles under dry and humid conditions: kinetics, mechanism and implications, Atmos. Chem. Phys., 15, 6851-6866, doi:10.5194/acp-15-6851-2015, 2015.

Wu, R. R., Bo, Y., Li, J., Li, L. Y., Li, Y. Q., and Xie, S. D.: Method to establish the emission inventory of anthropogenic volatile organic compounds in China and its application in the period 20082012, Atmos. Environ., 127, 244-254, 2016.

Ye, N. N.: Observations and budget analysis of ambient nitrous acid (HONO) in Wangdu, a rural site in North China Plain, Master thesis, Peking University, China, 2015.

Yokelson, R. J., Crounse, J. D., DeCarlo, P. F., Karl, T., Urbanski, S., Atlas, E., Campos, T., Shinozuka, Y., Kapustin, V., Clarke, A. D., Weinheimer, A., Knapp, D. J., Montzka, D. D., Holloway, J., Weibring, P., Flocke, F., Zheng, W., Toohey, D., Wennberg, P. O., Wiedinmyer, C., Mauldin, L., Fried, A., Richter, D., Walega, J., Jimenez, J. L., Adachi, K., Buseck, P. R., Hall, S. R., and Shetter, R.: Emissions from biomass burning in the Yucatan, Atmos. Chem. Phys., 9, 5785-5812, doi:10.5194/acp-9-5785-2009, 2009.

Yuan, Z. B., Lau, A. K. H., Shao, M., Louie, P. K. K., Liu, S. C., and Zhu, T.: Source analysis of volatile organic compounds by positive matrix factorization in urban and rural environments in Beijing, J. Geophys. Res., 114, D00G15, doi:10.1029/2008JD011190, 2009.
Zhang, L., Brook, J. R., and Vet, R.: A revised parameterization for gaseous dry deposition in air-quality models, Atmos. Chem. Phys., 3, 2067-2082, doi:10.5194/acp-3-2067-2003, 2003.

Zhang, R. Y., Wang, G. H., Guo, S., Zamora, M. L., Ying, Q., Lin, Y., Wang, W. G., Hu, M., and Wang, Y.: Formation of urban fine particulate matter, Chem. Rev., 115, 3803-3855, 2015.

Zhang, X., Chen, Z. M., He, S. Z., Hua, W., Zhao, Y., and Li, J. L.: Peroxyacetic acid in urban and rural atmosphere: concentration, feedback on PAN-NO $x$ cycle and implication on radical chemistry, Atmos. Chem. Phys., 10, 737-748, doi:10.5194/acp10-737-2010, 2010.

Zhang, X., He, S. Z., Chen, Z. M., Zhao, Y., and Hua, W.: Methyl hydroperoxide $\left(\mathrm{CH}_{3} \mathrm{OOH}\right)$ in urban, suburban and rural atmosphere: ambient concentration, budget, and contribution to the atmospheric oxidizing capacity, Atmos. Chem. Phys., 12, 89518962, doi:10.5194/acp-12-8951-2012, 2012.

Zhang, Y., Huang, W., Cai, T. Q., Fang, D. Q., Wang, Y. Q., Song, J., $\mathrm{Hu}, \mathrm{M}$., and Zhang, Y. X.: Concentrations and chemical compositions of fine particles $\left(\mathrm{PM}_{2.5}\right)$ during haze and non-haze days in Beijing, Atmos. Res., 174, 62-69, 2016.

Zhao, R., Lee, A. K. Y., Soong, R., Simpson, A. J., and Abbatt, J. P. D.: Formation of aqueous-phase $\alpha$-hydroxyhydroperoxides $(\alpha$ HHP): potential atmospheric impacts, Atmos. Chem. Phys., 13, 5857-5872, doi:10.5194/acp-13-5857-2013, 2013.

Zhao, Y., Chen, Z. M., Shen, X. L., and Huang, D.: Heterogeneous reactions of gaseous hydrogen peroxide on pristine and acidic gas-processed calcium carbonate particles: Effects of relative humidity and surface coverage of coating, Atmos. Environ., 67, 63$72,2013$.

Zheng, G. J., Duan, F. K., Su, H., Ma, Y. L., Cheng, Y., Zheng, B., Zhang, Q., Huang, T., Kimoto, T., Chang, D., Pöschl, U., Cheng, Y. F., and He, K. B.: Exploring the severe winter haze in Beijing: the impact of synoptic weather, regional transport and heterogeneous reactions, Atmos. Chem. Phys., 15, 2969-2983, doi:10.5194/acp-15-2969-2015, 2015.

Zheng, G. J., Duan, F. K., Ma, Y. L., Zhang, Q., Huang, T., Kimoto, T. K., Cheng, Y. F., Su, H., and He, K. B.: Episode-based evolution pattern analysis of haze pollution: method development and results from Beijing, China, Environ. Sci. Technol., 50, 46324641, 2016.

Ziemann, P. J. and Atkinson, R.: Kinetics, products, and mechanisms of secondary organic aerosol formation, Chem. Soc. Rev., 41, 6582-6605, 2012. 